\title{
IDENTIFICATION OF SACCHARINA GROENLANDICA (PHAEOPHYCEAE) AROUND THE SVALBARD ARCHIPELAGO: DNA BARCODING USING CYTOCHROME C OXIDASE SUBUNIT 1 (COI)
}

\author{
A Thesis \\ presented to \\ the Faculty of California Polytechnic State University, \\ San Luis Obispo
}

In Partial Fulfillment

of the Requirements for the Degree

Master of Science in Biology

by

Anniken Marie Lydon

March 2015 
(C) 2015

Anniken Marie Lydon

ALL RIGHTS RESERVED 
COMMITTEE MEMBERSHIP

TITLE:

AUTHOR:

DATE SUBMITTED:

COMMITTEE CHAIR:

COMMITTEE MEMBER:

COMMITTEE MEMBER:
Identification of Saccharina groenlandica

(Phaeophyceae) around the Svalbard

Archipelago: DNA barcoding using

cytochrome $c$ oxidase subunit 1 (COI)

Anniken Marie Lydon

March 2015

Francis Villablanca, Ph.D.

Professor of Biological Sciences

California Polytechnic State University, San Luis

Obispo

Mark Moline, Ph.D.

Director of University of Delaware School of

Marine Science and Policy

Michael Black, Ph.D.

Professor of Biological Sciences

California Polytechnic State University, San Luis Obispo 


\begin{abstract}
Identification of Saccharina groenlandica (Phaeophyceae) around the Svalbard Archipelago: DNA barcoding using cytochrome $c$ oxidase subunit 1 (COI)
\end{abstract}

\begin{abstract}
Anniken Lydon
In the Arctic, brown algae (kelps) and seaweeds are ecologically important: providing habitat, protection, and nutrients for invertebrate and vertebrate species living in nearshore environments. Migrations of biota between the North Pacific and North Atlantic Oceans have occurred periodically during Earth's history leading to colonization of the Arctic Ocean. Around 3.5 Mya the "Great Trans-Arctic Biotic Interchange" occurred and the Laminariales order of kelp, thought to be of North Pacific origin, underwent a massive radiation and speciation event around the Arctic Ocean. Phylogenetic analysis performed on "Laminaria-like" specimens collected from six sampling locations around the Svalbard Archipelago identified both the presence of Saccharina groenlandica and Laminaria digitata. This research represents new records for the presence of $S$. groenlandica around the Svalbard Archipelago. S. groenlandica and $L$. digitata exhibit phenotypic similarities such that these two species can be difficult to tell apart in the field. In this study we have shown that the COI gene region can be used for DNA barcoding and can provide species level resolution between these two cryptic species. Prior to this study and Lund (2014), a number of biodiversity studies conducted around the Svalbard Archipelago identified the presence of L. digitata in a number of locations around the archipelago, however S. groenlandica was not identified in any of these prior studies. Phylogenetic analysis conducted here showed that all Svalbard specimens of $S$. groenlandica had identical COI sequences and up to $0.30 \%$ sequence diversity with $S$. groenlandica specimens from other parts of the Arctic Ocean. Further analysis is needed to understand the abundance of this newly recorded species around the archipelago and to investigate both the timing of arrival and mechanisms of colonization.
\end{abstract}

Keywords: Saccharina groenlandica, Laminaria digitata, Svalbard, Laminariales, Phaeophyceae, DNA barcoding, cytochrome $c$ oxidase, COI 


\section{ACKNOWLEDGMENTS}

I would especially like to thank Dr. Mark Moline for the mentoring, funding and support for this project. Dr. Francis Villablanca for his numerous conversations and help on the phylogenetic analysis. Dr. Michael Black for his assistance with troubleshooting the molecular work. Dr. Geir Johnsen, Dr. Tove Gabrielsen, Dr. Jørgen Berge for their assistance in collection of specimens, help in understanding Svalbard ecosystems and in assisting with the logistics of this research project in Norway. Thank you to Elen Belseth for collecting specimens from Trondheim, Norway.

I would like to express my gratitude to my parents and family for their continued support throughout this project and in life. In addition I am extremely grateful to Johanna Weston for being such a supportive, and caring friend. Special thanks to Ian Robbins, for all his support. I am extremely grateful to Sarah Knudsen, Loredana Serafini, Sarah Johnson, Elizabeth Bridenstine, Melissa Daugherty, Jamie George, and Yasmine Akky for their friendship and continued support.

Special thanks to the University Center in Svalbard (UNIS), CSU COAST, and NORUS programs for providing funding for travel to the research site, supplies and equipment for this project. 


\section{TABLE OF CONTENTS}

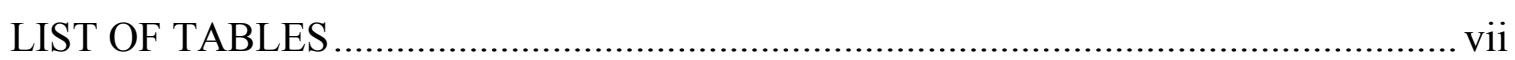

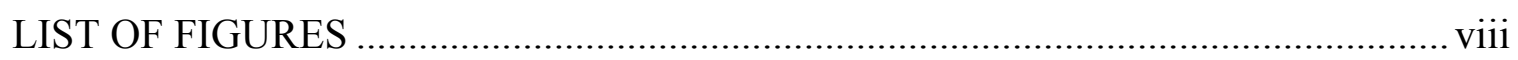

\section{CHAPTER}

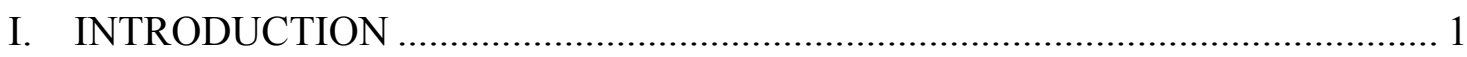

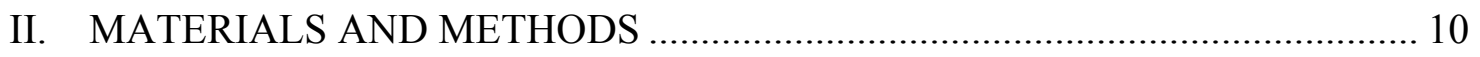

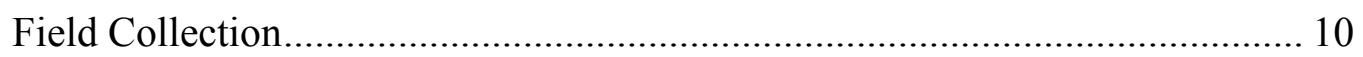

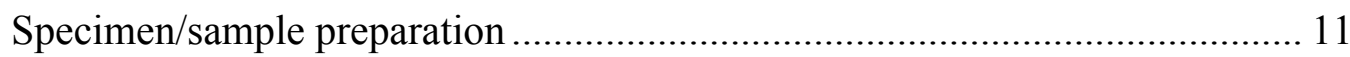

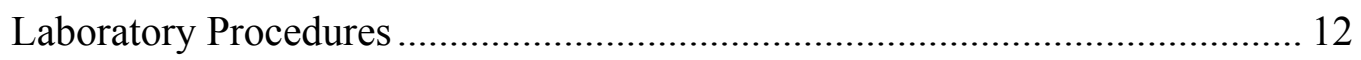

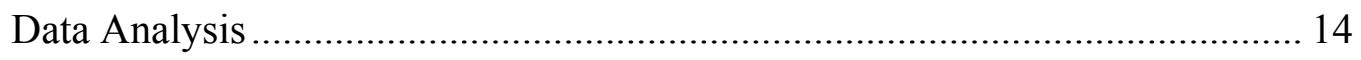

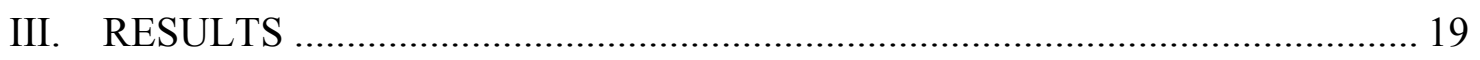

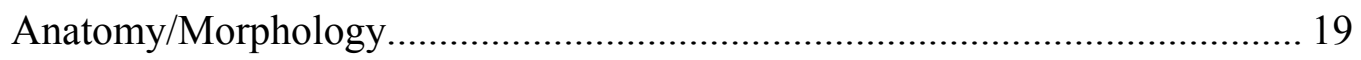

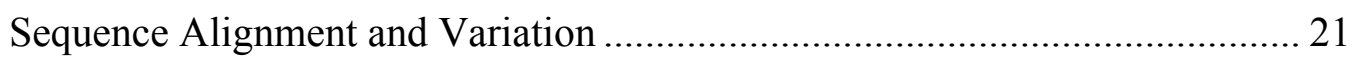

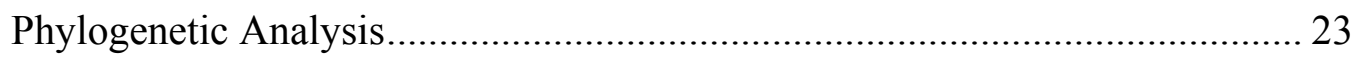

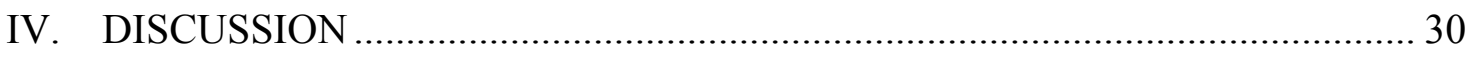

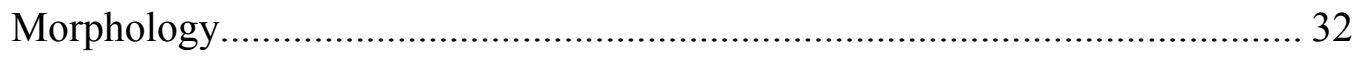

Phylogenetic Relationships ......................................................................... 35

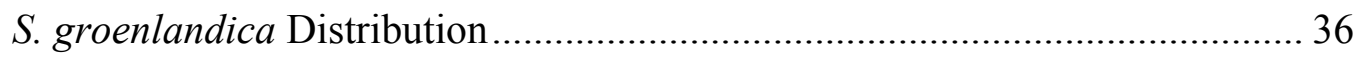

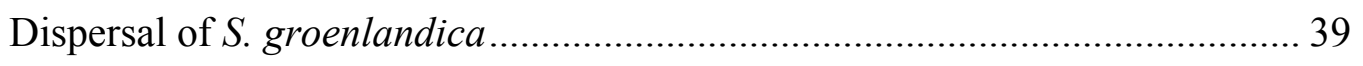

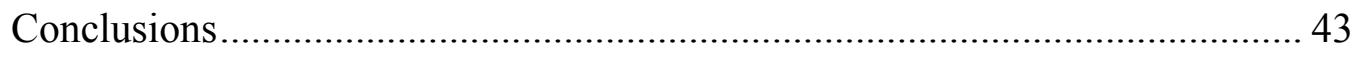

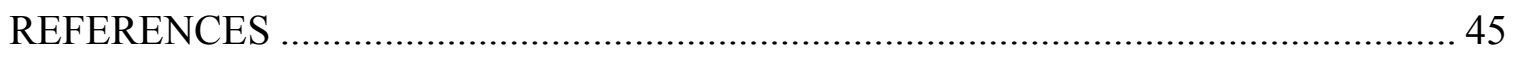

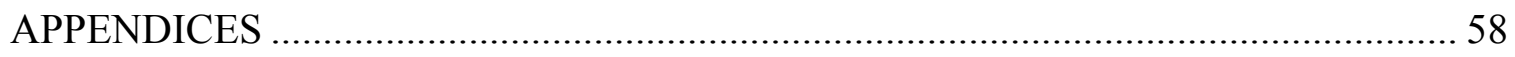

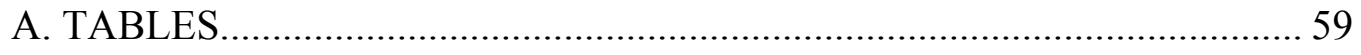

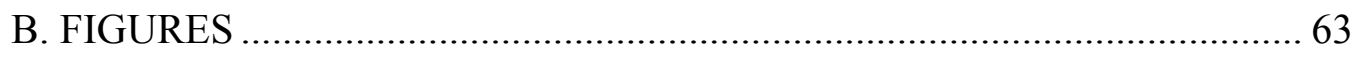




\section{LIST OF TABLES}

Table

Table 1. Sampling locations, collection dates, Lat/Lon (degrees minutes seconds), and number of specimens collected subtidally at each sample site.

Table 2. Measurements of morphological features collected on individuals $(n=7)$ from the Tommeløya population $\left(79^{\circ} 33^{\prime} \mathrm{N}, 18^{\circ} 44^{\prime} \mathrm{E}\right)$ on August 29, 2009 near the island of Tommelen in the Hinlopen Strait.

Table 3. Matrix of actual pairwise nucleotide differences between all L. digitata and $S$. groenlandica specimens used in this analysis. Actual PAUP* outputs shown in Figs. 14-18.

Table 4. The number of $L$. digitata and $S$. groenlandica species identified at each sampling location based upon DNA barcoding using the COI gene region. A total of 61 sequences from 59 specimens were used in the phylogenetic analysis 


\section{LIST OF FIGURES}

Figure $\quad$ Page

Figure 1. Map of Svalbard Archipelago and the sampling locations for this study. Samples collected in spring 2009 and fall 2010 aboard the $R / V$ Jan Mayen. All six sampling sites around the Svalbard Archipelago are marked with black squares. The Trondheim sampling site, which is located on the coast of Norway, is not shown on this map.

Figure 2. Specimens collected subtidally near the island of Sagaskjæret, Isfjord, Svalbard (78 $12^{\prime} 34.2^{\prime \prime}$ N, 1356'29.0”E) on August 25, 2009. Samples collected between 5-12 m depth. (a-f) illustrate the digitate and "strap-like" nature of the specimens collected around Sagaskjæret, near the mouth or outer portion of Isfjord,(g) samples of meristematic tissue collected from the transition zone between the blade and stipe from individual blades for specimens collected at this location.

Figure 3. Specimens collected subtidally near the island of Tommeløya $\left(79^{\circ} 33^{\prime} \mathrm{N}\right.$, $\left.18^{\circ} 44^{\prime} \mathrm{E}\right)$, Hinlopen Strait on August 29, 2009 aboard the $R / V$ Jan Mayen. Samples collected from depths between 3-5 meters. (a) processing and collection of $5 \mathrm{~cm}$ by $5 \mathrm{~cm}$ tissue samples, (b-c) photographs of different specimens (whole) collected, (d-i) Individual specimens numbered 1-7, (k) POC/PON samples collected from specimen 1, (1) POC/PON samples collected from specimen 4, and (m) POC/PON samples collected from specimen 6 . This population possessed a rather short stipe length to blade length.

Figure 4. Specimens collected subtidally near the island of Rossøya $\left(80^{\circ} 49^{\prime} \mathrm{N}\right.$, $20^{\circ} 18^{\prime} \mathrm{E}$ ). Samples collected by divers subtidally at around $10-15 \mathrm{~m}$ depth. Samples were numbered after harvesting tissues and most of the specimens brought up by divers only consisted of the meristematic region of the blade/stipe. (a-i) illustrate the variety of phenotypes present in the area, (d) specimen exhibiting distinct bullae present on the blade, which is a morphological trait more typically associated with a $S$. groenlandica than $L$. digitata. 
Figure 5. Specimens collected on May 13, 2010 offshore of Bjørndalen

(Fuglefjellet), in Isfjord (78 $13^{\prime} 2.42^{\prime \prime} \mathrm{N}, 15^{\circ} 15^{\prime} 30.42$ 'E) on May 13, 2010.

These specimens were collected subtidally on the opposite side of Isfjord from the Sagaskjæret population.

Figure 6. Specimens collected on July 5, 2010 near Trondheim Biological Station, Trondheimsfjord, Norway (6326'28.53"N, 10²0'56.13"E). Specimens collected subtidally and photos were taken of the first six samples. (a) specimen 1, (b-c) specimen 2 blade and cross-section (x-section), (d-e) specimen 3 blade and stipe $\mathrm{x}$-section, (f-g) specimen 4 blade and stipe $\mathrm{x}$ section, (h-i) specimen 5 blade and stipe $\mathrm{x}$-section, and (j-k) specimen 6 blade and stipe $\mathrm{x}$-section. These specimens were identified as L. digitata based upon DNA barcoding with the COI gene region.

Figure 7. Gel electrophoresis (1.5\% agarose gel stained with EtBr) of cytochrome $c$ oxidase I (COI) PCR products from the Tommeløya, Ny Ålesund, and Rossøya populations compared with a $1 \mathrm{~kb}$ DNA ladder. Expected amplicon length of $658 \mathrm{bp}$ for all specimens. Lanes 2-12 (2.T_22, 3.T_23, 4.T_24, 5.T_26,6.T_27, 7.T_28,8.T_29C,9.Tommeloya \#1, 10.Tommeloya \#4, 11.NA_03a, 12.Empty) and Lanes 14-17 (14.Lsoli\#19, 15.Lsoli\#22, 16.Lsoli\#25, 17.R_10) correspond to COI sequences for Svalbard samples. Lane 18 shows the positive control $(+)$ and Lane 19 shows the negative control (-). Lanes 21-24 were empty.

Figure 8. Gel electrophoresis (1.5\% agarose gel stained with EtBr) of internal transcribed spacer region (ITS) PCR products from the Tommeløya, Ny Ålesund, and Rossøya populations compared to a $1 \mathrm{~kb}$ DNA ladder. Expected amplicon lengths: $S$. groenlandica $=739 \mathrm{bp}$, L. digitata $=739 \mathrm{bp}$ and $L$. solidungula $=740 \mathrm{bp}$. Lanes 2-11 and 17 (2.T_22, 3.T_23, 4.T_24, 5.T_26, 6.T_27,7.T_28,8.T_29C,9. Tommeløya \#1, 10. Tommeløya \#4, 11.NA_03a, 17.R_10) correspond to $S$. groenlandica and Lanes 14-16 (14.Lsoli\#19, 15.Lsoli\#22, 16.Lsoli\#25) show L. solidungula COI sequences for Svalbard samples. Lane 18 shows the positive control (+) and Lane 19 shows the negative control (-). Lanes 12, 21-24 were empty. .70

Figure 9. Chromatogram/trace alignments of forward and reverse reads of the ITS sequence using Chromas Pro software to align and check the reads for a specimen from the Tommeløya population. At nucleotide site 192 there appears to be an ambiguous base call, that may represent a polymorphic site in the ITS region. 
Figure 10. Neighbor-joining tree using only sequences from McDevit \& Saunders (2009) to recreate a phylogram of species relatedness to compare methods utilized in this study with those utilized by McDevit \& Saunders (2009). Tree created by enforcing the GTR model of evolution and arbitrarily rooting the tree on the Fucus sp. branch.

Figure 11. Neighbor-joining (NJ) phylogram of sequences derived from this study and analyzed with McDevit \& Saunders (2009) COI sequences (BOLD 2014). Distances corrected using the GTR model of evolution. McDevit \& Saunders (2009) taxon shown in black. Taxon for sequences derived in this study shown in red. .73

Figure 12. Neighbor-joining phylogram enforcing a GTR model of evolution for all unique COI sequences from the McDevit \& Saunders (2009) data set and sequences derived in this study. Bootstrap values (nreps=1000) are shown above each branch. The McDevit \& Saunders (2009) taxon based on BOLD identification numbers (McDevit and Saunders 2009) are shown in black text. Taxon derived from this study shown in red.

Figure 13. Parsimony tree (heuristic search nreps=40) of all unique COI sequences from McDevit \& Saunders (2009) and all sequences derived from this study. Fifty percent majority rule bootstrap values (nreps=1000) are shown above or below the appropriate branches. Taxon from McDevit \& Saunders (2009) are shown in black text. Taxon derived in this study shown in red text. Scale bar indicates a tree length of 30.0 .

Figure 14. Maximum likelihood phylogram enforcing the TVM $+\mathrm{I}+\mathrm{G}$ model of evolution and substitution for the COI gene region using the McDevit \& Saunders (2009) and sequences derived here. McDevit \& Saunders (2009) taxon shown in black text. Sequences derived in this study shown in red text. Bootstrap values (nreps $=20$ ) are shown above or below the appropriate branch. .76

Figure 15. Maximum likelihood tree enforcing the TPM1uf $+\mathrm{I}+\mathrm{G}$ model of evolution for the COI gene region. Fifty-percent majority rule bootstrap (nreps $=1000)$ values are shown above or below the appropriate branch. Taxon derived from this study shown in red text. Taxon from McDevit \& Saunders (2009) shown in black text.

Figure 16. Actual interspecific nucleotide pairwise differences between Laminaria digitata (MACR0272_06) and Saccharina groenlandica (MACR0232_06, MACR0245_06 and T_29C_H1_121004). .78 
Figure 17. Actual interspecific nucleotide pairwise differences between Laminaria digitata (LDN17C_G2_120807) and Saccharina groenlandica (MACR0232_06, MACR0245_06 and T_29C_H1_121004).

Figure 18. Actual intraspecific nucleotide pairwise differences for $L$. digitata sequences from McDevit \& Saunders (2009) (MACRO272_06_Laminaria digitata), the NA_18 specimen from Ny Ålesund and the North Wales sample LdNWAL17 (tissue sample courtesy of the Claire Lab, Roscoff, France)

Figure 19. Actual interspecific nucleotide pairwise differences between Laminaria digitata (NA18aC_H6_121004) and Saccharina groenlandica (MACR0232_06, MACR0245_06 and T_29C_H1_121004).

Figure 20. Actual intraspecific nucleotide pairwise differences between Saccharina groenlandica sequences (MACR0232_06, MACR0245_06 and T_29C_H1_121004).

Figure 21. COI DNA sequences for select Laminariaceae specimens showing the coded amino acids. A nucleotide change at position 106 in the MACRO232_06 and MACRO245_06 results in an amino acid change in these $S$. groenlandica amino acid sequence from a serine (S) to a proline (P) 


\section{INTRODUCTION}

In the Arctic Polar Region, brown algae (kelps) and other seaweeds are ecologically important: providing habitat, protection against wave action, and supplying nutrients for invertebrate and vertebrate species living in nearshore environments (Yoon et al. 2001; Schiel \& Foster 2006; Wiencke et al. 2006; Graham et al. 2009). Kelps are among the most "productive vegetation types" in the world (Dring 1982) and contribute largely to coastal biomass in temperate and polar coastal regions. In addition to providing essential habitat for many marine species, kelps are also highly valued commercial commodities in many countries and used in various foods, cosmetics, agricultural, medicinal and industrial products. In 1994/1995, seaweeds had an estimated global worth of \$6.2 billion (U.S.) dollars (Zemke-White \& Ohno 1999). More recently, the United Nations estimated the global value of the seaweeds at \$5.5-6 billion (U.S.) annually (UN FAO Fisheries Department 2004). As climate change impacts coastal nearshore environments, understanding the ecological and economic implications of changes in kelp forest dynamics, species composition, and distribution patterns will become increasingly important.

Global climate change influences the distribution patterns of many species on earth; causing shifts in their habitat ranges over time. Due to the severe environmental seasonality of Polar Regions, organisms in these areas are likely to be noticeably affected by climate change prior to those at lower latitudes (Carmack et al. 2006; Sakshaug et al. 2009; Wassman et al. 2010). The Arctic has experienced rapid warming over the past 50 
years (Moline et al. 2008) and offers unique opportunities to study the influence of environmental variation on species distribution patterns (Renaud et al. 2008), both foreshadowing potential patterns of change in species distributions at lower latitudes, as well as providing insight into the past dynamics. Shifts in habitat ranges or intrusions of new species may mean the loss of characteristically Arctic species from areas of the Arctic (Wassman et al. 2010), if native organisms are unable to find suitable refugia.

The Earth's past glacial and inter-glacial periods impacted ecological conditions, geographic connections, and the movement of species; leading to the modern distribution of kelps and other seaweeds around the Arctic Ocean. The modern Arctic Ocean consists of two basins, which remain connected to temperate coasts across broad continental shelves (Grantz et al. 1990). The connections between the Arctic Ocean and temperate coasts resulted in assemblages of seaweeds in the Arctic that are less isolated than those in the Antarctic (Wiencke et al. 2006). Antarctic flora was isolated from other southern continents around 26 million years ago (Mya) during the development of the Antarctic Circumpolar Current (Lüning 1990; Wiencke et al. 2006). This long period of isolation resulted in a higher degree of endemism in the Antarctic than the Arctic and in different biodiversity and species compositions between the two Polar Regions. For example, the Antarctic Ocean does not contain any kelp in the Laminariales order (Moe \& Silva 1977). However, both Polar Regions are relatively low in species richness as compared to temperate coasts (Wiencke et al. 2006). The Arctic Ocean is estimated to have about 150 species present (Wilce 1994), with approximately 70 of these species occurring around the Svalbard Area (Weslawski et al. 1993, 1997; Vinogradova 1995). Within the Arctic 
Ocean, macroalgal species richness is higher near the North Atlantic and decreases towards the Pacific (Wiencke et al. 2006).

Migrations of marine biota between the North Pacific and North Atlantic Oceans, via the Arctic Ocean, occurred periodically during the Tertiary period of Earth's history. Around 3.5 Mya the "Great Trans-Arctic Biotic Interchange" occurred and the Laminariales order of kelp, thought to be of North Pacific origin (Bolton 2010), underwent a massive radiation and speciation event (Adey et al. 2008; Graham et al. 2009). After the Pleistocene, which ended about 11,700 years ago, the biotic exchange between the North Pacific and North Atlantic appeared to cease. However, the exchange between the Arctic and the North Atlantic continues today and is dependent upon dispersal mechanisms, temperature adaptations and environmental tolerances for different species (Lüning 1990; Wilce 1990). Today about 90\% of the modern flora of seaweeds in the Arctic originates from Atlantic populations (Dunton 1992). Algal habitat ranges and distribution patterns are often limited by the upper survival temperature (UST) for gametophytes/sporophytes or the upper limit for gametogenesis (ULG) for a particular species (Wiencke et al. 2006). The ice ages during Earth's history made Polar Regions ecologically stressful or unsuitable for some seaweeds (ibid.), which resulted in smaller geographical ranges for many different Northern Atlantic seaweeds (Van den Hoek \& Breeman 1989; Wiencke et al. 2006).

For much of the Tertiary period, the Arctic Ocean supported temperate biota (Briggs 1995, 2003). Cooling of the Arctic Ocean is thought to have occurred sometime during the middle to late Miocene (Lüning 1990; Bolton 2010) and may have limited dispersal and connections between populations located on different sides of the Arctic 
Ocean: very few species within the Laminariales order occur in the Arctic Ocean and both the North Pacific and North Atlantic temperate coasts (ibid.). Perennial ice cover is thought to have first formed sometime later than 3 Mya (Briggs 1995, 2003) and has been estimated to have started around 0.7-2.0 Mya (Clarke 1990). The extreme low temperatures, variable light climate, and ice cover in the Arctic environment lead to a number of adaptations in Arctic macroalgae. Polar seaweeds, including kelps, are well adapted to low light conditions during much of the year, growth in depths up to 30-90 m, and physiologically adapted to handle annual environmental variability in salinity, irradiance, temperature, and sea ice extent (Wilce 1994; Wiencke et al. 2006).

Perennial Arctic kelps experience seasonal growth patterns and reproduction cued in response to daylength (circannual rhythm), temperature, and nutrient levels (Lüning 1988). There is evidence that some kelps have adapted physiological mechanisms for survival in the Arctic environment, including: varying photosynthetic and respiratory efficiencies, varying defenses against herbivory across tissues, and other cellular mechanisms to handle the extreme environment (Wiencke et al. 2006). Many polar kelp species are physiologically shade-adapted and fully functional at low temperatures. Additionally, these kelps are also impacted by fast-ice formation along the shoreline and the subsequent ice scour, which leaves open habitat (barren zones) in the upper subtidal environment and down to a few meters depth. Ice scouring, herbivory and UVB radiation can impact kelp zonation patterns in the Arctic (Hanelt et al. 2001; Wiencke et al. 2006).

Studies on seaweeds and kelps in the Arctic first began around the 1850's (Wiencke et al. 2006). Kjellman (1883) first catalogued large-scale seaweed distribution patterns in the Arctic Ocean around Russia, the Bearing Sea and Spitsbergen (Svalbard 
Archipelago) and Rosenvinge (1898) catalogued species around Greenland. Past studies around Spitsbergen focused on identifying macroalgal biogeographic distributions (Svendsen 1959). In the 1990's studies of seaweed biogeography and ecophysiology around Spitsbergen greatly increased (Wiencke et al. 2006). Some researchers have recently started conducting resurveys of previously studied areas in an attempt to assess long-term changes in macroalgal communities around Svalbard (Fredriksen et al. 2014) in response to climate change.

Many recent studies have assessed community level biodiversity changes, including both flora and fauna, (Weslawski et al. 1993, 1997, 2011; Gulliksen et al. 1999; Lippert et al. 2001; Beuchel et al. 2006, 2010; Renaud et al. 2008) to evaluate climate change impacts around the archipelago. A number of these studies emphasize an important biogeographic conclusion: the return of boreal and sub-boreal species to the Svalbard Archipelago from lower latitudes (Berge et al. 2005, 2009; Beuchel et al. 2006, 2010; Renaud et al. 2008) in response to climate variation. Additionally, many surveys have identified similarities between the species composition of benthic communities around Svalbard and those along the coast of Norway (Gulliksen et al. 1999; Rueness et al. 2001). Notably, the Norwegian Sea continental shelf supports a greater diversity of macrofauna than the European Arctic shelf around Svalbard (Renaud et al. 2008; Weslawski et al. 2011). The benthic communities present around Svalbard have been postulated to be "impoverished" communities of the Norwegian Coast (ibid.).

Evidence and modeling suggests that transport of lower latitude species to the Arctic is likely driven by the Western Spitsbergen Current (WSC), which is an extension of the North Atlantic Current (NAC) that flows along the coast of Norway before heading 
north towards Spitsbergen (Berge et al. 2005; Beuchel et al. 2006; Kedra 2008; Kedra et al. 2010). Today, the WSC provides $70 \%$ of the in-flow into the Arctic Ocean (Dickson et al. 1999). Modeling indicates that the transport of water masses between the coast of Norway and the west coast of Spitsbergen takes a minimum of about 32 to 38 days to cover the $1000 \mathrm{~km}$ distance (Berge et al. 2005). Some organisms with planktonic life stages may disperse to the archipelago via the WSC (ibid.). While many past biodiversity studies have noted shifts in species ranges around the archipelago or the return of lower latitude species; Weslawski et al. (2011) suggested that no new marine species had colonized the Svalbard Archipelago. However, a survey conducted in 2012/2013 suggested that some new species of marine flora were found in areas around the archipelago (Fredriksen et al. 2014)

The subtidal kelp forests around Spitsbergen (Figure 1) are documented as being dominated by Alaria esculenta, Laminaria digitata, Saccharina latissima (formerly Laminaria saccharina), and L. solidungula in the inner parts of fjords, and red algae Phycodrys rubens and Ptilota gunneri in the lower subtidal environments (Svendsen 1959; Hop et al. 2002; Wiencke et al. 2004). Members of the Laminariaceae typically exhibit heteromorphic alternation of generation and have much larger macroscopic sporophytes than gametophytes (Graham et al. 2009). This type of life history strategy is thought to be an adaptation for dealing with environmental conditions typical of temperate, boreal and polar regions (John 1994). The Laminaria and Saccharina genera dominating the upper subtidal environment of the Archipelago are perennial species persisting for multiple seasons. Most species within the Laminariaceae exhibit either an 
entire blade or a split blade, but species within the Laminaria or Saccharina genera do not have a midrib (Setchell \& Gardner 1925; Graham et al. 2009).

Traditionally, taxonomic classification has relied on identifiable morphological or phenotypic traits for species identification. And often, species identification can be complicated by environmental conditions during the time of the survey, presence of cryptic species (Schander \& Willassen 2005), and phenotypic plasticity in response to environmental conditions (Lüning 1979; Van Alstyne et al. 1999; McDevit \& Saunders 2010). More recently, molecular methods have been used to further support traditional classifications and distributional patterns of species, or resolve evolutionary relationships between different species of algae (Boo et al. 1999; Yoon et al. 2001; Lane et al. 2006). DNA barcoding offers a very useful genetic tool for assessing biogeographic distribution in marine ecosystems (Schander \& Willassen 2005; McDevit \& Saunders 2009, 2010).

Phycologists use many different molecular regions for phylogenetic assessment of evolutionary relationships between species of the Laminariales order, including: the internal transcribed spacer (ITS) region (Yoon et al. 2001; Tai et al. 2001; Lane et al. 2006); small or large ribosomal subunit DNA (SSU or LSU rDNA) (Boo et al. 1999; Tai et al. 2001; Lane et al. 2006); chloroplast RuBisCo spacer regions (including the large subunit ( $r b c \mathrm{~L})$, spacer, and small subunit $(r b c \mathrm{~S}))$ (Boo et al. 1999; Lane et al. 2006); and both the mitochondrial NADH dehydrogenase subunit 6 (nad6) (Lane et al. 2006) and the cytochrome $c$ oxidase I ( $\operatorname{cox} 1$, referred to here as COI) (Saunders 2005; McDevit \& Saunders 2009, 2010). Recent phylogenetic assessment of the Laminariales order called for a reorganization of the "ancestral" clade and the "derived" ALL families including: Alariaceae, Laminariaceae and Lessoniaceae (The "ALL" families, Lane et al. 2006). 
The three derived ALL families were classified based upon traditional morphological traits such as blade and stipe morphology, presence of mucilaginous organs in tissues of the sporophytes, meiospores lacking an eyespot, sperm flagellation and production of the sexual pheromone lamoxirene (Kawai \& Sasaki 2000; Muller et al. 1985). Lane et al. (2006) identified two distinct clades within the Laminariaceae family and called for the resurrection of the generic name Saccharina Stackhouse (1809) to describe the clade of species within the Laminariaceae that did not cluster with the type for the genus (Laminaria digitata).

Although the ITS region has been widely used to elucidate species level differentiation and phylogenetic relationships (Tai et al. 2001; Lane et al. 2006), McDevit \& Saunders (2009) demonstrated that the COI gene region provides a more appropriate genomic region for species level differentiation between macroalgal specimens while providing similar phylogenetic resolution to the more commonly used ITS region. In addition, the COI region encompasses a full mitochondrial protein coding gene that does not contain internal transcribed spacer regions, which makes sequence alignments less difficult, less subjective and requires fewer user assumptions about rates of gene evolution, evolution of gene size or placement of insertions/deletions.

DNA barcoding can be utilized for understanding the evolutionary history and relatedness between species, but also for identification of unknown specimens (McDevit \& Saunders 2009, 2010). Many species of macroalgae exhibit phenotypic plasticity in response to environmental variables (Graham et al. 2009) and thus may be difficult to distinguish during field surveys (McDevit \& Saunders 2010). This argues that DNA barcoding should be used to supplement species identification in addition to the use of 
traditional morphological traits. In addition, DNA barcoding provides researchers with methods for identifying specimens from only small amounts of tissue without having the whole specimen, while also allowing for species identification or verification of voucher materials.

During research cruises aboard the $R / V$ Jan Mayen in August, September 2009 and May 2010, roughly 200 algal specimens were collected from different fjord systems around the Svalbard Archipelago. Initially specimens were classified as L. digitata, based upon morphological characteristics of the blade, stipe and haptera. At that time, specimens were intended for a study to address population genetic structure through an assessment of microsatellite variation (Billot et al. 1998, 2003). However, unsuccessful amplification of microsatellite regions raised questions regarding the species identity of the algal specimens collected during the 2009 and 2010 research cruises. Sequencing of the nuclear ITS and mitochondrial COI regions and phylogenetic analysis was used to properly identify each specimen using molecular barcoding in addition to the initial morphological identification. We have discovered S. groenlandica samples that were initially regarded as $100 \%$ L. digitata. Given this result, this report addresses the following four hypotheses:(1) COI DNA data can be used for identification of multiple unknown "Laminaria-like" specimens collected around the Svalbard Archipelago, (2) More than one sample of S. groenlandica is found around the Svalbard archipelago, such that, (3) The unknown species' distribution is widespread around the archipelago, and (4) COI DNA provides population-level resolution for this previously unrecognized species found around the Svalbard Archipelago. 


\section{MATERIALS AND METHODS}

\section{Field Collection}

All algal specimens were collected around the Svalbard Archipelago, aboard the $R / V$ Jan Mayen during research cruises, in late summer/fall of 2009 and spring of 2010 (Figure 1, Table 1). Scientific divers collected subtidal specimens from various fjord systems around the Svalbard Archipelago and Trondheim Fjord, Norway (Table 1). Divers were instructed to collect $L$. digitata specimens, with clear digitate blade morphology, from an approximate 50 meter by 50 meter subtidal area (similar to methods used in Billot et al. 2003). The divers collected tissue from the transition zone between the stipe and blade, which contains the meristematic blade tissue, as well as a few whole individuals for visual assessment of gross morphology for the specimens. A total of 213 "Laminaria-like" morphotype specimens and four L. solidungula specimens were collected: near Ymerbukta (Sagaskjæret population), Isfjord; near Kjeglefjella (Bjørndalen population), Isfjord; Ny Ålesund, Kongsfjord; in Smeerengburgfjord; around Rossøya near Rijpfjord; near Tommeløya in the Hinlopen Strait; and near the Trondheim Biological Station in Trondheimsfjord, Norway. Most sampling locations around Svalbard, were around the island of Spitsbergen, with the exception of the Rossøya population sampled near Nordaustlandet (Figure 1).

Once collected, the specimens were held at in situ temperatures with running seawater until further processing. Some of the whole specimens from the populations were photographed, but photographs were not taken for all populations or all individuals 
within the populations because morphological characterization of $L$. digitata was not the original intent of this study. Specimens were given a unique identifier indicating the sampling location, the collection date, and the specimen number. A $5-\mathrm{cm}^{2}$ section of meristematic tissue was removed from the blade of each specimen, just above the single unbranched stipe. Each tissue sample was then placed in silica beads in a Ziploc bag and allowed to completely dry at room temperature in a cool, dark location. Dried tissue samples were shipped from Norway to the California Polytechnic State University (Cal Poly), San Luis Obispo campus in California for further laboratory processing and analysis.

\section{Specimen/sample preparation}

A $2-\mathrm{cm}^{2}$ piece of dried algal tissue was placed into a sterile mortar (see below for sterilization methods) and immersed in liquid nitrogen. The tissue was ground into a fine

powder using the mortar and pestle at room temperature, then collected in a microcentrifuge tube and stored at $-20^{\circ} \mathrm{C}$ until ready for DNA extraction. All equipment was cleaned and sterilized between sample grinding to prevent cross contamination between tissue specimens. Sterilization and cleaning procedures for mortars/pestles after tissue grinding included: (1) an initial wash with soapy water to remove tissue remnants, (2) rinse in Nanopure, (3) incubation in 6\% Bleach solution for at least a 15 minute soak as recommended by Kemp \& Smith (2005), (4) rinse in Nanopure, (5) time to dry, (6) rinse in $95 \%$ Ethanol and flame sterilize, and (7) mortars and pestles were exposed to UVB light for a minimum of one hour prior to processing the next tissue sample. 


\section{Laboratory Procedures}

Due to the high number of specimens collected and the relatively low cost of DNA extraction kits, the ZR Fungal/Bacterial DNA Miniprep kit (Zymo Research Corporation, Irvine, CA, USA) was chosen for DNA extraction because of its similarity to many plant DNA extraction kits: plus its added benefit of mechanical tissue break up using microbeads (ZR BashingBead technology). A small amount of the ground algal tissue (between 5-10 mg) was placed into DNA extraction tube. DNA extraction was performed according to manufacturer-supplied protocols. DNA extraction and tissue processing included the following steps: (1) addition of $750 \mu 1$ of lysis solution (Tris, $\mathrm{NaCl}$, EDTA) to each extraction tube; (2) secure tubes in a bead beater and run at $4.5 \mathrm{~m} / \mathrm{s}$ for 45 seconds; (3) pellet excess tissue at 14,000 rpm for 1 minute (Beckman Coulter Digital Microfuge 18 Centrifuge; 14,000 rpm F241.5P Rotor; Beckman Coulter, Indianapolis, IN); (4) collect up to $400 \mu 1$ of the supernatant, transfer to a Zymo-Spin IV Spin Filter in a collection tube and centrifuge at 7,000 rpm; (5) add $1200 \mu 1$ of the Fungal/Bacterial Binding Buffer with 0.5\% (v/v) beta-mercaptoethanol to the filtrate; (6) transfer up to $800 \mu \mathrm{l}$ of the filtrate/buffer mix to a new Zymo-Spin IIC column collection tube and centrifuge at 14,000 rpm for 1 minute; (7) repeat step 6 with the remaining filtrate/buffer mix; (8) discarded the filtrate from and keep the column filter; (9) wash the filter by adding $200 \mu \mathrm{l}$ of DNA Pre-Wash Buffer to the IIC Spin column; (10) centrifuge at 14,000 rpm for 1 minute; (11) add $500 \mu 1$ of Fungal/Bacterial DNA Wash Buffer to the column filter; (12) centrifuge at 14,000 rpm for 1 minute; (13) transfer washed filter with bound DNA to a new $1.5 \mathrm{ml}$ microcentrifuge tube; (14) add $50 \mu \mathrm{l}$ of DNA Elution Buffer 
to the column matrix; (15) centrifuge at 14,000 rpm for 30 seconds to elute the DNA; and (16) store DNA extract at $-20^{\circ} \mathrm{C}$ prior to $\mathrm{PCR}$ amplification.

In some instances, DNA extracts proved difficult to amplify. Amplification may have been inhibited by extracellular polysaccharides and polyphenolic compounds held in the algal tissues (Wiencke et al. 2004; Graham et al. 2009), which may have co-extracted during DNA extraction. Genomic DNA obtained using the ZR Fungal/Bacterial kit yielded amplifiable DNA for about 130 of the 213 tissue samples.

DNA was amplified at both the mitochondrial COI (cytochrome $c$ oxidase I, 658 bp) (Figure 7) and nuclear ITS (ribosomal internal transcribed spacer region (ITS15.8SrDNA-ITS2), about $740 \mathrm{bp}$ ) (Figure 8) gene regions using the GAZF2/GAZR2 (Lane et al. 2007), and the ITSP1/KG4 (Tai et al. 2001; Lane et al. 2006) primers at $0.4 \mu \mathrm{M}$ concentration per PCR tube. All PCR reactions were performed in $25 \mu$ reaction tubes using $1.0 \mu \mathrm{l}$ of undiluted DNA extract in a tube with Taq Polymerase plus Taq 2X Master Mix (New England Biolabs, Ipswich, Massachusetts, USA). DNA was amplified in either a Biometra T3 Thermocycler (Biometra, Gottingen, Germany) or GeneAmp Thermal Cycler (Applied Biosystems, Foster City, California, USA). The thermal amplification profile for both the ITS and COI DNA regions included: an initial denaturing step of $95^{\circ} \mathrm{C}$ for 3.0 minutes; followed by 38 cycles of $95^{\circ} \mathrm{C}$ for 30 seconds, $50^{\circ} \mathrm{C}$ for 45 seconds, $68^{\circ} \mathrm{C}$ for 1.0 minute; and a final extension step at $68^{\circ} \mathrm{C}$ for 10.0 minutes and a $4^{\circ} \mathrm{C}$ hold until the sample was removed and place into a $-20^{\circ} \mathrm{C}$ freezer.

PCR amplicons were visualized on a $1.5 \%$ agarose gel (Figure 7 , Figure 8) to check for successful amplification. PCR reactions tubes containing amplified products of interest were held at $-20^{\circ} \mathrm{C}$ until the product could be purified from the Master Mix and 
excess polymerase enzyme using the Zymo Clean and Concentrator Kit (Zymo Research Corporation, Irvine, CA, USA) and eluted into $50.0 \mu 1$ of elution buffer. PCR amplicon DNA concentrations were measured using a Nanodrop ND-1000 Spectrophotometer (Thermo Fisher Scientific, Wilmington, Delaware, USA). PCR products were then added to a 96-well plate with a final concentration of $10 \mathrm{ng} / \mu \mathrm{l}$ per well and prepared for sequencing. All forward reads were processed on one plate and reverse reads processed on another plate. The 96-well plates were shipped to Retrogen, Inc. (San Diego, California, USA) for sequencing using the Applied Biosystems (Foster City, California, USA) capillary ABI 3730 dye terminator sequencing. Forward and reverse chromatograms/traces were aligned and visually inspected using ChromasPro Version 1.5 (Technelysium Pty Ltd.) for sequence verification.

\section{Data Analysis}

Intragenomic polymorphic sites (ambiguous sites in the sequence) were considered sites where: (1) at least two nucleotides were equally represented at a single nucleotide position in the chromatogram, and (2) the peak heights (magnitude) for the nucleotide bases at that site were at least half the magnitude of other adjacent peaks in the chromatogram (Figure 9). These intragenomic polymorphic site criteria, listed below, were specifically developed to address potential issues in the nuclear (diploid) ITS region, but were also utilized for the COI region. Polymorphic sites in the DNA sequence were considered to be truly polymorphic and not merely noise or poor base-calling if the following rules applied:

1. Multiple peaks at a single nucleotide position were present in both the forward and reverse read chromatograms. 
2. The height of any secondary peak at a particular nucleotide position had to be at least relatively half the intensity (half as tall) as the base called by the ABI 3730 sequencing software.

3. Peak heights for the two or more bases at the polymorphic site must be smaller than peak heights for adjacent nucleotide sites in the chromatogram.

4. Then appropriate IUPAC letter designation was used to represent the polymorphism present at the particular nucleotide position and the sequence was saved.

5. Additionally, if a single polymorphic site was present in the DNA sequence, then two copies of the DNA sequence were also saved; one copy for each of the different equally likely alleles.

6. If more than one polymorphic site was identified in the DNA sequence, then determination of allelic combinations (phase) was not possible; in these instances, all polymorphic sites were strictly represented by the appropriate IUPAC letter.

Partitioning the data by geographic population was a manageable method for identifying sequences that were too short (not the full extent of a particular gene region), which were removed from further analysis. Population data files were aligned using Clustal W (EMBL-EBI 2007) to create an initial population alignment in NEXUS format. Multiple sequence alignments (MSA) were then edited in MacClade version 4.08 (Maddison \& Maddison 2005). Aligned sequence NEXUS files were exported. Additionally, previously published/vouchered Laminariales sequences (McDevit and Saunders 2009) were downloaded from the Barcode of Life (BOLD) website and 
combined with the sequences developed in this study. Phylogenetic analysis of the relationships between DNA sequences derived in this study and previously published sequences was performed in PAUP* 4.0b (Swofford 2002). The BOLD accessions numbers were used as taxa names for all McDevit \& Saunders (2009) sequences downloaded and incorporated into this analysis.

Initial analysis followed phylogenetic methods used by McDevit \& Saunders (2009) to develop phylogenetic trees using the nuclear ITS and mitochondrial COI gene regions. A neighbor-joining (NJ) tree was created using only McDevit \& Saunders (2009) COI sequence data to visualize phylogenetic relationships between sequences (Figure 10); as a check that the parameters/models of evolution being used in the analysis yielded results similar to previously published work (McDevit \& Saunders 2009). The aim was to recreate the McDevit \& Saunders (2009) topology, and then later add new sequences from this study to identify specimens and evaluate phylogenetic relationships. In this manner we showed that our analytical methods alone do not yield the novel result presented here: identification of S. groenlandica around Svalbard.

Following this exercise, only full-length COI DNA sequences for the Svalbard specimens were added to the previously published sequences and evaluated using the same phylogenetic tree methods (ibid.). A neighbor-joining (NJ) tree was created, using a general time reversible model of evolution for distance corrections. The general time reversible model (GTR) is the most general, neutral, independent, finite-sites, timereversible model possible. The phylogenetic tree was arbitrarily rooted on the Fucus genus branch similar to the methods used by McDevit \& Saunders (2009) to visualize 
phylogenetic relationships between different species of the Phaeophyceae class of algae (Figure 11).

In addition to only using full-length sequences, DNA sequences were evaluated to identify only unique sequences within the data set. If a sequence was identical to others in the data set (more than one individual with the same sequence), only one representative sequence was retained. This allowed for less computation time during the bootstrap analysis, and made visualizations of the phylogenetic relationships easier. Using only the unique sequences in the data set, a bootstrap analysis (nreps=1000) was performed to assess the level of branch support in the phylogenetic tree created using the GTR evolutionary model and neighbor-joining distance methods for the tree topology discussed above (Figure 12). McDevit \& Saunders (2009) did not perform bootstrapping because they were not concerned with creating a rigorous phylogeny for the specimens analyzed, but wanted to identify whether COI could be used for DNA barcoding and show similar phylogenetic resolution to the ITS gene region.

Additionally, sequence data was evaluated using the maximum parsimony method to derive the tree topology and phylogenetic relationships. A heuristic search with 40 replicates, adding sequences randomly, and using the tree-bisection-reconnection algorithm of branch swapping was performed to obtain the tree topology using the parsimony criterion. The Fucus genus was designated as the outgroup. Bootstrap analysis for maximum parsimony was run with 1000 replicates and ten random sequence addition replicates per bootstrap replicate.

Sequence data was then analyzed using the most appropriate evolutionary model for the COI gene in a maximum likelihood analysis (Guindon \& Gascuel 2003) following 
a model selection analysis using the jModelTest 2.1.3 software program (Darriba et al. 2012). Initial model search criteria in jModelTest were set to evaluate 11 substitution schemes (JC,HKY,TN,TPM1,TPM2,TPM3,TIM1,TIM2,TIM3,TVM,GTR) with allowance for invariable sites $(+\mathrm{I})$, unequal base frequencies $(+\mathrm{F})$, and rate heterogeneity $(+\mathrm{G})$, with the rates being defined by a gamma distribution (nCat=4). The BIONJ tree building topology was initially used as described below in the results, then the evolutionary model evaluation in jModelTest was rerun using maximum likelihood (ML) tree building to determine if different evolutionary models fit the sequence data set depending upon the initial input criteria. Selection of the best fit model was based upon the Akaike Information Criterion (AIC) (Johnson \& Omland 2004). Each "best fit" evolutionary model was then enforced in PAUP* and a neighbor-joining tree was used to quickly visualize phylogenetic relationships under the given model. An additional step, not performed here, would be to perform model averaging for the evolutionary models (ibid.). All trees and analysis in PAUP* were exported, visualized, manipulated and annotated in the FigTree (version 1.4, Rambaut 2006) software program. 


\section{RESULTS}

\section{Anatomy/Morphology}

Fifty-one of the fifty-nine subtidal specimens that were collected and identified as L. digitata were later identified as $S$. groenlandica (Table 4), based upon the full COI sequences. Many of the specimens collected around the Svalbard Archipelago (Figures 26) exhibited morphological traits similar to $S$. groenlandica species, namely: branching haptera, blades/thallus being either entire or split into two or more horizontal segments, and a flexible stipe (Setchell \& Gardner 1925). Morphologically, S. groenlandica has been described as typically developing a branching holdfast (haptera), stipe with a maximum length of $60 \mathrm{~cm}$, which is cylindrical near the holdfast and then appears flattened near the base of the blade/thallus (Setchell \& Gardner 1925; Druehl 1968; Algaebase 2014). Few specimens collected in this study exhibited the bullate or ruffled blade morphology described (Algaebase 2014) for younger stages of $S$. groenlandica species, suggesting that the collected specimens were older sporophytes, likely $2^{\text {nd }}$ or $3^{\text {rd }}$ year specimens similar to those analyzed by Druehl et al. (1987). Many specimens from Svalbard had digitate type blades (Figure 2 a \& b, Figure 4, Figure 5) with only a few horizontal blade slits or segments, while the L. digitata (Figure 6) specimens collected from Trondheim showed a digitate blade morphology with many segments. The small number of segments observed on the blades for most Svalbard specimens appeared more similar to the description of $S$. groenlandica morphology than to the number of segments observed for the L. digitata specimens collected from Trondheim (Figure 6). 
Measurements of morphological characteristics, including individual thallus length, stipe length and maximum haptera diameter, for the Tommeløya population (Figure 3) showed an average $(\mathrm{n}=7)$ thallus length of $35.5 \mathrm{~cm}+2.3 \mathrm{~cm}$, mean stipe length of $7.4 \mathrm{~cm}+1.6 \mathrm{~cm}$, and mean maximum haptera diameter of $6.4 \mathrm{~cm}+0.7 \mathrm{~cm}$ (Table 2). In many instances, qualitative assessments of gross morphology were not possible during sample processing: as often divers only collected enough meristematic tissue to obtain the necessary $5 \mathrm{~cm}$ by $5 \mathrm{~cm}$ tissue sample and not the entire specimen. During field collection, it was not anticipated that data regarding the morphological features of the specimens would be beneficial in the later analysis and these measurements were often not taken. Based upon qualitative assessments of the specimens from various populations, the Tommeløya specimens appeared to have a shorter thallus length and shorter stipe length than specimens from other sampling locations. Therefore, the Tommeløya morphological measurements are likely not representative of the morphological characteristics of all S. groenlandica from other parts of the archipelago (Figures 2-6). Some specimens from the Tommeløya population (Figure 3) showed a slightly bullate blade morphology, which is more characteristic of young S. groenlandica specimens.

The Sagaskjæret sporophyte specimens collected from Isfjord appeared to show thicker tissues and more "strap-like" thallus segments (Figure 2) than some of the other populations around the Svalbard Archipelago. The Rossøya population (Figure 4) and the Bjørndalen/Fuglefjellet populations (Figure 5) contained sporophyte individuals with much thinner tissue. The morphological characteristics of the Svalbard algal specimens appeared slightly different than those described for S. groenlandica specimens collected in the North Pacific and Canadian Arctic (Druehl 1970; Druehl et al. 1987; McDevit \& 
Saunders 2009, 2010; Algaebase 2014). In many cases, samples from Svalbard had segmented, smooth blades that did not exhibit much of the bullate thallus characteristic on the sporophyte (Figures 2-6); making these specimens even more difficult to distinguish in situ from L. digitata individuals that may co-occur in the same subtidal areas. The qualitative assessments and quantitative measurements collected for specimens from Svalbard indicated that most specimens showed morphological characteristics more similar to S. groenlandica than L. digitata.

\section{Sequence Alignment and Variation}

DNA extraction from the 213 individuals collected around the Svalbard Archipelago yielded about 165 COI PCR products representing 139 different specimens (Figure 7, Figure 8). Not all 165 COI PCR products returned high quality sequence data using the $\mathrm{ABI} 3730$ sequencer; for some PCR products, the DNA concentration may have been too low during the sequencing reactions or inhibitors may have been present in the PCR product. The ABI 3730 dye terminator sequencing system provided high quality chromatograms (Figure 9) for a number of PCR products. Sequences were obtained for PCR amplicons of both the nuclear ITS and mitochondrial COI gene regions for various specimens. Alignments of the forward and reverse traces were visually inspected and the traces for the COI sequences aligned rather easily. Of the 139 COI PCR products sequenced, only 61 products returned sequences of appropriate quality and length for use in the phylogenetic analysis. For many of the PCR products the length of the high quality sequence was too short and was not used in the phylogenetic analysis here.

In addition to the sixty-one full length COI sequences from Svalbard and Trondheim specimens, 119 previously published COI sequences (McDevit \& Saunders 
2009) were downloaded (Barcode of Life Database) and used to assess phylogenetic relationships between the collected specimens and other members of the Laminariales and verify the species identification for Svalbard specimens (collected here) through DNA barcoding. Of the 61 sequences from this study, 59 specimens were represented: 54 specimens from Svalbard, four specimens from Trondheim, and one L. digitata control sample from a specimen in North Wales (Valero Lab, Roscoff, France).

The COI gene region was about 658 base pairs (bp) in length for all sequences analyzed here. The $61 \mathrm{COI}$ gene sequences generated aligned well with the 119 sequences previously published sequences; the COI gene region did not contain any gaps or indels in the MSA. Sequence alignments in Clustal W, identified 3 groupings for the Svalbard specimens. These groupings coincided with reference sequences for $S$. groenlandica, L. digitata and L. solidungula. All the Svalbard S. groenlandica specimens appeared to have the same sequence. Distance matrix values calculated in PAUP* indicated that all $S$. groenlandica specimens from Svalbard had identical sequences. The Svalbard S. groenlandica sequences differed slightly from S. groenlandica sequences from other parts of the Arctic (McDevit \& Saunders 2009) by 1-2 actual nucleotides (Table 3) and the within species variation (sequence diversity) was $0.0-0.30 \%$.

The two Svalbard L. digitata specimens, both from Ny Ålesund, had identical sequences to the four specimens from Trondheim, Norway. The molecular distances were zero between all $L$. digitata sequences in this analysis, and thus are representative of the same sequence (Table 3). The $L$. digitata within species variation was equal to $0.00 \%$. The actual nucleotide pairwise differences (Figures 16-20) between L. digitata and $S$. 
groenlandica sequences indicated there were 59-60 nucleotide differences between the two species (Table 3), which is $8.96-9.12 \%$ sequence divergence.

\section{Phylogenetic Analysis}

Phylogenetic analysis further described below indicated that $S$. groenlandica was found at all six sampled sites around the Svalbard Archipelago (Figure 1). In this particular study, L. digitata was only found at the Ny Ålesund sampling location and not at any other sites around the Archipelago. Thus $S$. groenlandica appears to replace $L$. digitata in most sampled areas around Svalbard and co-occurs with $L$. digitata near $\mathrm{Ny}$ Ålesund in Kongsfjord.

(1) Neighbor-joining Distance Methods (McDevit \& Saunders (2009) data):

Initial phylogenetic distance analysis of only the 119 previously published COI sequences (McDevit \& Saunders 2009) verified the rooting methods utilized by McDevit \& Saunders (2009) and also validated the software workflow used in this study (Figure 10). The software workflow and methods used here resolved similar phylogenetic relationships to McDevit \& Saunders (2009), which enforced a general time reversible (GTR) model of evolution to obtain the particular neighbor-joining tree topology. Differences between Figure 10 and McDevit \& Saunders (2009)'s tree included differences in resolution of the relationships between members of the Alariaceae and Laminariaceae families. In Figure 10, the Laminariaceae family remained paraphyletic as a result of the Macrocystis integrifolia/Nereocystis luetkeana branch, which clustered separately from all other Laminariaceae sequences. Figure 10 indicated that the Laminaria genus and Saccharina genus are sister 
taxa forming a monophyletic group and were more closely related than identified in McDevit \& Saunders (2009). Importantly, Laminaria and Saccharina form distinct (monophyletic) clades, such that there is no ambiguity of sequence assignment or placement into one clade versus the other.

(2) Neighbor-joining Distance Pooled COI data:

Distance analysis run in PAUP*, using the 180 COI sequences and enforcing the GTR evolutionary model indicated that 53 sequences of the 61 COI sequences derived in this study were S. groenlandica (Figure 11). One $S$. groenlandica specimen had three sequences in the analysis as a check for PCR quality control. There were $5 S$. groenlandica specimens identified in the $\mathrm{Ny}$ Ålesund population, 10 in the Tommeløya population, 12 in the Rossøya population, 6 in the Sagaskjæret population, 10 in the Bjørndalen population, 8 in the Smeerenburg population, and none were found in the Trondheim population (Table 4). There was one L. solidungula specimen from Svalbard that clustered with the previously published $L$. solidungula sequence, as anticipated. Two specimens from the Ny Ålesund population and the four samples from the Trondheim population were identified as L. digitata based upon the COI sequence data and the analysis was performed according to McDevit \& Saunders (2009) methods (Figure 11).

The COI sequence data was condensed down from 180 sequences to 50 sequences representing only the unique sequences/alleles within the data set: for ease of visualization and speed of downstream analysis. A neighbor- 
joining phylogenetic tree was recreated and it did not appear to change the gross tree topology, discussed above, or the phylogenetic relationships much; the Laminariaceae appeared to be a monophyletic group within this analysis (Figure 12) and included clustering of the Saccharina and Laminaria genera as sister taxa forming a monophyletic group, similar to previously created phylogenetic trees (Figure 10, Figure 11).

(3) Parsimony and Bootstrap Analysis:

Parsimony criterion analysis performed in PAUP* using 40 heuristic search replicates with tree-bisection-reconnection (TBR) yielded six equally parsimonious trees for the 50 unique COI sequences and using the Fucus genus as the outgroup. All six parsimony trees had a tree length of 1237, a consistency index (CI) of 0.3791 , homoplasy index of 0.6209 and a retention index (RI) of 0.7013 . There were 386 constant sequence characters/sites and 233 parsimony-informative sites. The resulting tree topology and subsequent bootstrap analysis (nreps=1000) showed $100 \%$ support for the $S$. groenlandica and L. digitata branches (Figure 13), providing further evidence that a majority of the specimens collected around the Svalbard archipelago, represented by sample T_29C_H1_121004, were S. groenlandica. The Laminariaceae family again appears paraphyletic with the Alariaceae clustering within the Laminariaceae, however the bootstrap values are not well supported at many of these nodes. Bootstrap values for placement of the M. integrifolia/N. luetkeana were weak (65\% support) and may help explain some of the observed differences between the parsimony trees (Figure 13) and 
other phylogenetic trees analyzed here. In this parsimony analysis, the Saccharina genus and Laminaria genera did not resolve as sister taxa as they had in previous trees created using distance methods. It appeared that the parsimony analysis did not perform well with these AT rich sequences where transitions outnumber transversions.

The two Svalbard L. digitata samples again appear identical to the four Trondheim specimens and the $L$. digitata sequences from McDevit \& Saunders (2009). These phylogenetic relationships were well supported by a $100 \%$ bootstrap value (Figure 13). Unfortunately, there were no photographs taken of the Ny Ålesund L. digitata specimens during collection or tissue processing.

(4) Maximum Likelihood Methods and Bootstrap Analysis:

A.) ModelTest analysis, using a specified BIONJ base tree topology for maximum likelihood calculations, identified the $\mathrm{TVM}+\mathrm{I}+\mathrm{G}$ evolutionary substitution model as the "best fit" model for the 50 COI sequence data set. The sequence data had invariant sites $(+\mathrm{I})$, unequal base frequencies with A-T bias $(A=0.25320, C=0.13970, G=0.15550, T=0.45160)$ and rate heterogeneity among nucleotide sites, as described by a gamma $(+G)$ distribution with a shape parameter of 0.772 and four rate categories. Transitions were estimated to occur about six times more than transversions.

Maximum likelihood analysis enforcing the $\mathrm{TVM}+\mathrm{I}+\mathrm{G}$ evolutionary model (-ln L of 6128.6881) and subsequent bootstrap analysis (nreps=20) yielded bootstrap supports of $100 \%$ and $95 \%$ for the L. digitata and $S$. 
groenlandica branches respectively (Figure 14). There was also 95\% bootstrap support for the Saccharina genus and only $65 \%$ bootstrap in the Laminaria genus, not including the L. yezoensis specimen. The Laminariaceae family was again paraphyletic due to the placement of the M. integrifolia/N. luetkeana branch. The Laminaria genus and Saccharina genus again appeared to be sister taxa, although this branch did not have $>50 \%$ bootstrap support. Many of the branches in this tree showed little bootstrap support, for example the $55 \%$ branch support leading to the ALL (Alariaceae, Laminariaceae, and Lessoniaceae) families and including the Costariaceae. There was not much bootstrap support for the ALL families, and thus this branch and the phylogenetic relationships between these families remains somewhat less well resolved through the use of only the COI mitochondrial locus.

Again, the T_29C_H1_121004 Svalbard sample sequence resolved with other S. groenlandica samples with a $95 \%$ bootstrap value ( $\mathrm{n}=20 \mathrm{reps}$ ). Bootstrap results under the above conditions showed 100\% bootstrap support for the $L$. digitata cluster of sequences, which included the representative Svalbard NA18aC_H6_121004 specimen from the Ny Ålesund population.

B.) ModelTest analysis, using the least constrained inputs, identified the TPM1 $\mathrm{u}+\mathrm{I}+\mathrm{G}$ substitution model as the "best fit" model for this data set. The sequence data had invariant sites $(+\mathrm{I})$, unequal base frequencies with an A-T bias $(A=0.25020, C=0.13680, G=0.15640, T=0.45660)$ and rate heterogeneity among nucleotide sites, as described by a gamma $(+\mathrm{G})$ distribution with shape parameter of 0.7360 and 4 rate categories. Transitions were estimated to occur 
about six times more than transversions. In nuclear genes, the ratio of transitions to transversions is usually between $0.5-2$, but this can be much larger in mitochondrial genes (Nei \& Kumar 2000), which is consistent with the ratios observed here.

Bootstrap analysis ( $n=1000$ reps) of the phylogram, created using the TPM1uf $+\mathrm{I}+\mathrm{G}$ (Figure 15) evolutionary model, showed 100\% support for both the S. groenlandica and L. digitata branches. The Saccharina genus and Laminaria genus appeared to be sister taxa, but phylogenetic relationships between the ALL families, plus Costariaceae, were not well resolved using this COI data set. The Laminariaceae family was again paraphyletic. The Alariaceae and Costariaceae families were monophyletic. The Lessoniaceae (Eisenia arborea, Egregia menziessi) family also did not resolve as a monophyletic group. The phylogeny created using the TPM1uf $+\mathrm{I}+\mathrm{G}$ model of evolution appears to show similar phylogenetic relationships to other previously evaluated trees in this analysis.

Most of the Svalbard specimens collected and originally identified as L. digitata, were identified as $S$. groenlandica based upon the COI sequencing data and phylogenetic analysis. All phylogenetic approaches employed here provide evidence that most "Laminaria-like" specimens collected around the Svalbard archipelago, originally thought to be L. digitata, were $S$. groenlandica. These results must be a function of the relationships of the sequences, since they are unlikely to be an artifact of the analytical methods. The $S$. groenlandica sequences differed by 1-2 actual nucleotides between Svalbard specimens and those from other parts of the Arctic (Table 3). S. groenlandica 
around Svalbard (represented by T_29C_H1_121004) appeared to have a thymine (T) present at nucleotide position 106 of the COI gene region. Presence of a thymine (T) at this sequence position may reflect the ancestral trait at this site, since the majority of the other species in the data set also have a thymine present at this nucleotide position. However, the S. groenlandica specimens from other regions of the Arctic (MACR0232_06 and MACR0245_06) had an adenine (A) at this sequence position. Although, this change at position 106 appears to occur at the first position of a codon and would result in an amino acid sequence change from a serine, which is coded for in the T_29C_H1_121004 Svalbard specimen and many other taxa in the analysis, to a proline in the amino acid sequence (Figure 21).

In addition MACR0232_06 and MACR0245_06 (McDevit \& Saunders 2009), both S. groenlandica, differed from each other at nucleotide position 414, where MACR0232_06 appears to have switched from the ancestral trait of possessing a cytosine (C) at this site and instead had a thymine (T) present at this nucleotide position. However, the difference observed at site 414 between MACR0232_06 and MACR0245_06 appears to be a third position nucleotide and results in a phenylalanine amino acid for both specimens. Although there were observable differences in the COI gene sequence between $S$. groenlandica sequences in this analysis (up to $0.30 \%$ divergence), there did not appear to be enough resolution to observe population-level genetic structure or phylogeographic relationships using the COI locus alone. 


\section{DISCUSSION}

Based upon previous studies using the COI gene region for species identification within the Laminariaceae (McDevit \& Saunders 2009) and knowledge that phenotypic plasticity is well documented in algal families (Graham et al. 2009; McDevit \& Saunders 2010), the following hypotheses were tested in this study: (1) COI DNA data can be used for identification of multiple unknown "Laminaria-like" specimens collected around the Svalbard Archipelago, (2) More than one sample of S. groenlandica is found around the Svalbard Archipelago, such that, (3) The unknown species' distribution is widespread around the archipelago, and (4) COI DNA provides population-level resolution for this previously unrecognized species found around the Svalbard Archipelago. Results indicate that: (1) the COI sequence data and phylogenetic analyses performed in this study confirmed that the COI mitochondrial gene region provides a useful tool to resolve the identity of the unknown "Laminaria-like" specimens collected around Svalbard (McDevit \& Saunders 2009, 2010; Lund 2014), (2) most of the "Laminaria-like" specimens collected around the archipelago were identified as Saccharina groenlandica (Rosenvinge 1893) C.E. Lane, C. Mayes, Druehl \& G.W. Saunders: confirming the presence of this species around the archipelago, (3) the geographic distribution of the $S$. groenlandica is widespread and occurred at every sampling location around the archipelago, and (4) the COI sequence data in this analysis did not provide enough resolution to identify population-level genetic structure for $S$. groenlandica in different geographic areas of the archipelago; sequences were identical and didn't provide enough 
resolution to determine modes of migration or colonization of $S$. groenlandica around the archipelago.

While the COI mitochondrial gene region offers a good molecular tool for species identification, used in conjunction with morphological characteristics, this gene region did not provide the resolution necessary to evaluate population-level genetic structure. McDevit and Saunders (2010) identified regional differences in S. groenlandica based upon the ocean where the specimens were collected (Pacific, Atlantic, Arctic). There did appear to be slight regional differences between the $S$. groenlandica Svalbard specimens and specimens collected in other parts of the Arctic Ocean. However, the COI region alone does not provide necessary sequence variability needed to answer questions regarding mechanisms of migration and the timing of colonization, as mentioned above.

Previous authors, using a combination of different DNA regions, have suggested that the ITS region exhibits higher diversity (up to about 30\% in Lane et. al. 2006; McDevit \& Saunders 2010) and may provide some insight into population-level or regional genetic structure. The ITS region is the most commonly used non-plastid region for phylogenetic analysis in plants and algae (Tai et al. 2001; Lane et al. 2006, 2007; Feliner \& Rossello 2007). This gene region: requires a number of assumptions regarding concerted evolution through gene conversion or unequal-crossover (Feliner \& Rossello 2007), can be difficult to align above the generic level (McDevit \& Saunders 2009) due to gaps/indels, and includes regions subject to different evolutionary pressures and rates of change (Leclerc et al. 1998).

During this research, 162 ITS sequences were also generated (data not shown or analyzed here) and a few of the nucleotide sites for these sequences appeared to be 
polymorphic (Figure 9). Further analysis of the ITS sequence data may elucidate populations-level genetic structure for S. groenlandica specimens around Svalbard and other parts of the Arctic (McDevit \& Saunders 2010). Additionally, development of microsatellite markers (Balloux \& Lugon-Moulin 2002) for S. groenlandica could also enhance understanding of population genetic structure, migration, and dispersal mechanisms. This additional data may provide some insight into the broader question regarding large-scale modes of kelp colonization around the Artic and may foreshadow future change.

\section{Morphology}

The morphology of $S$. groenlandica varied widely across geographic locations around the Svalbard Archipelago and could be classified into different morphotypes (Figures 2-6) similar to what was observed by Lund (2014). The specimens from the Sagaskjæret population (Figure 2) exhibited a morphotype with a long, narrow lamina very similar to the morphology observed in Lund's Kapp Mitra population, which was collected near the outlet of Kongsfjord (Lund 2014). The Sagaskjæret population collection site for this study was located near the outlet of Isfjord. Perhaps the strap-like, long, narrow blade morphology observed for these S. groenlandica specimens is a growth response to the environmental conditions encountered near the mouth of the fjord systems, which tend to have stronger currents the inner areas of the fjord (Sakshaug et al. 2009).

The morphological observations during this study were qualitative, with the exception of morphological measurements collected on a few individuals from the Tommeløya population (Figure 3). For S. groenlandica around Svalbard, Lund (2014) 
measured morphological differences between geographic sites and found large differences in: the lamina/blade shape, angle between the lamina and stipe, and variation in stipe cross-section shape. Lund's (2014) work along with photographs and qualitative observations here suggests there is a large degree of phenotypic plasticity in $S$. groenlandica at different sites around the Svalbard Archipelago. Very few specimens collected during this study had bullae present on the blade. Specimens collected during this study may have been older individuals not exhibiting the bullate pattern typical of young S. groenlandica sporophytes (Druehl 1968). Or perhaps in response to some environmental condition present around the archipelago these specimens do not express this morphological feature.

Data from this study only identified a few L. digitata specimens and all were found in the Ny Ålesund sampling location (Figure 1). Additionally, S. groenlandica also occurred in this location. The presence/absence of mucilage ducts within the blade and stipe tissues is a useful morphological trait that can be used to distinguish between $S$. groenlandica and L. digitata (McDevit \& Saunders 2010). Mucilage ducts are present within both the blade and stipe tissues of S. groenlandica, while L. digitata only develops mucilage ducts in the blade tissue (ibid). Expression of these mucilage ducts was once thought to be a plastic feature developed in response to colder temperatures (Wilce 1965), but McDevit \& Saunders (2010) disputed this and reinforced the taxonomic utility of the mucilage duct morphological trait in distinguishing between species. However, this morphological feature requires assessment of the different regions of the algal specimen using a compound light microscope and may not a useful be useful for distinguishing between species during field surveys. 
Qualitative morphological differences between the L. digitata specimens from the Trondheim fjord and the $S$. groenlandica specimens found around the Svalbard archipelago mainly showed differences in the number of segments present on the blade, the color of the specimens, the tissue thickness and presence of the bullae on some blades. Lund (2014) found that often the L. digitata, mainly from Trondheim, showed a wide variety of morphological traits and in some cases specimens of $L$. digitata may not exhibit the characteristic segment blade morphology for this species. Thus, further complicating field identification between $L$. digitata and S. groenlandica.

The dehydrated tissue samples of L. digitata (LD_NWAL-17) shipped from France (Valero Lab) and S. groenlandica from Svalbard had very different colors; with the Svalbard specimens being much darker brown compared to the dark green/light brown tissue color of the dried L. digitata specimens. This appears to be another phenotypic difference observed between the $L$. digitata and $S$. groenlandica specimens. Lund (2014) also identified similar color differences between S. groenlandica and $L$. digitata when observed on a light box, which can also be seen when comparing Figure 6 to S. groenlandica specimens from around Svalbard (Figures 2-5). Perhaps color differences between specimens may be an additional tool for distinguishing between these species, especially if occurring in the same area.

Additionally, investigations into the causes of phenotypic plasticity exhibited by S. groenlandica could be conducted to identify cellular mechanisms and environmental conditions involved in expression of the large degree of phenotypic plasticity observed here and in Lund (2014). Previously researchers hypothesized that different current flows and velocities influenced the percentages of mannuronic and guluronic acid composing 
algal (Egregia menziesii) cell walls, which influences flexibility for the algae. These researchers found that the percentages of mannuronic and guluronic acid were not correlated with the environmental conditions tested (Kraemer \& Chapman 1991). However, others have shown that the percentages of mannuronic to guluronic acid in the algal cell walls vary seasonally (Graham et al. 2009). Understanding the degree of molecular and environmental control on phenotypic plasticity and expression of different morphotypes of $S$. groenlandica would provide researchers with a better idea of the reliability of some of the traditionally used morphological traits and whether these characteristics should be relied upon when distinguishing between species.

\section{Phylogenetic Relationships}

The cytochrome $c$ oxidase I (COI) gene is a protein coding region of the mitochondrial genome and codes for a membrane-bound protein that is highly important to electron transport across the mitochondrial inner membrane. This gene region exhibits slower rates of mutation than other regions within the genome. The COI region can be used to differentiate relationships between species and has been shown to have similar utility to the ITS region in resolving algal phylogenetic relationships (McDevit \& Saunders 2009).

Species-level identification based on the COI region was successful; all specimens collected around the Svalbard Archipelago were properly identified using DNA barcoding and had well supported species branches that were consistent across the different phylogenetic methods used (parsimony, distance-method, maximum likelihood). Although there were some branches, such as the M. integrifolia and $N$. luetkeana branches, which did not resolve well with the rest of the Laminariaceae family in most 
phylogenetic methods; the Saccharina and Laminaria genera resolved as sister taxa in all phylogenetic analyses with the exception of the parsimony analysis.

The analysis of the appropriate evolutionary model for the COI gene region and this data set indicated that both the TVMIG and TPM1ufIG were the best models under the different test conditions. Both models are appropriate for the given data set, are very similar, and allow for differing rates of substitution between different nucleotide bases. Coincidentally, Lund (2014) also reported the TPM1uf model as the best model for her data, however this model was not enforced during her phylogenetic analysis because this model was not available in the computer program used for the analysis.

The low bootstrap support values derived here for branches of the ALL families suggest that the COI region alone does not resolve family level and generic level relationships well. Additionally, this gene region did not provide much intraspecific variability and thus limits potential to draw major conclusions regarding intraspecific phylogeography of the S. groenlandica around the Arctic Ocean and regional patterns.

\section{S. groenlandica Distribution}

The North Pacific has much higher species richness than the Arctic North Atlantic (Wiencke et al. 2006). The algal distribution patterns for Arctic North Atlantic species show that the range limits in the western Atlantic are determined by the upper survival temperature (UST) and the upper limit for gametogenesis (ULG), which are determined by lethal, high summer temperatures. The distribution patterns of species in the Eastern Atlantic are mainly limited by high winter temperature that inhibits reproduction (ibid.).

S. groenlandica is found in the North Pacific from around Coos Bay, Oregon and throughout the Canadian Arctic to Nova Scotia, Eastern Greenland (Algaebase 2014; 
McDevit \& Saunders 2009, 2010) and has now been identified around the Svalbard Archipelago here and by Lund (2014).

The subtidal environment around the Svalbard Archipelago as thought to be dominated by many different species in the upper and the mid sublittoral zones by $L$. digitata, A. esculenta, and L. solidungula (Svendsen 1959; Hop et al. 2002; Wiencke et al. 2004; Wiencke et al. 2006). However, DNA barcoding performed here identified that many specimens around the Svalbard Archipelago that appear to be L. digitata were $S$. groenlandica, which was not known to exist around the archipelago until now. $S$. groenlandica was present throughout a large geographic range around the Svalbard Archipelago (Figure 1). S. groenlandica was also found in large abundance around the archipelago by Lund (2014) through similar molecular analysis of specimens from similar sampling location to those here. The work conducted here also verified the presence of L. digitata around the Svalbard Archipelago.

Results of this study showed that L. digitata and S. groenlandica co-occur in Kongsfjord, Svalbard. L. digitata specimens have been collected from Kongsfjorden for studies related to algal ecophysiology (Laturnus \& Mehrtens 2004; Wiencke et al. 2006). Additionally, many diversity surveys have identified the presence of L. digitata in various fjord systems around Svalbard and shown this species to be an important contributor to kelp forest biomass (Wiencke et al. 2004; Hop et al. 2012; Fredriksen et al. 2014). Fredriksen et al. (2014) identified a number of new marine brown algae in the Kongsfjord area that had arrived between surveys conducted in 1996/1998 and again in 2012/2013. Prior to the work discussed here, no previous surveys had identified $S$. groenlandica in the Kongsfjord area. The presence of this species in Kongsfjord was also 
verified by Lund (2014). Surveys of marine flora near the outer portion of Isfjord also did not identify the presence of $S$. groenlandica (Fredriksen \& Kile 2012), while the two populations (Sagaskjæret and Bjørndalen/Fuglefjellet) analyzed here using DNA barcoding only identified S. groenlandica specimens.

The COI sequences for all $S$. groenlandica Svalbard specimens from this study were identical, suggesting that these specimens are all descendant from a recent common ancestor or that this region evolves too slowly to detect differences. These sequences were very similar to the sequence from specimens collected around Canada (McDevit \& Saunders 2009), but differed by a few nucleotides. The collection of other specimens of S. groenlandica from other parts of the Arctic Ocean or the use of an alternative genomic region could help determine the mechanisms of migration. Additionally, information regarding the maximum dispersal distances for the spores of $S$. groenlandica and the upper limit for gametogenesis may help identify potential geographic range limitations for this species in the Arctic Ocean and mechanisms of dispersal to the Svalbard Archipelago.

Vertical distributions and zonation for $L$. digitata and many other species of Laminariaceae around the Svalbard Archipelago are dependent upon the availability of appropriate quantities of photosynthetically active radiation (PAR), potential exposure to UVB radiation (UVBR), competition with other species, and the degree of ice scour in the upper sublittoral (Hop et al. 2002; Wiencke et al. 2006; Hop et al. 2012). Most records place $L$. digitata specimens in the mid sublittoral zone in depths of 5-15 m (Svendsen 1959; Wiencke et al. 2004; Wlodarska-Kowalczuk et al. 2009). Biologically relevant levels of UVBR can reach down to depths of 5-8 $\mathrm{m}$ in clear Arctic waters during 
the spring and often the penetration depth decreases during the summer as melt water flows through rivers and carries sediment into the fjord waters, which leads to greater UVBR attenuation (Hanelt et al. 2001; Svendsen et al. 2002). Often UVBR can limit zonation depths by preventing germination of microscopic algal life stages of $L$. digitata and other species around the archipelago (Wiencke et al. 2006). Many kelp species possess phlorotannin-containing physodes, which act as a protective mechanism against cell damage caused by UVBR (Roleda et al. 2005, 2006; Wiencke et al. 2004). The $S$. groenlandica specimens identified here were collected in depths from 3-15 m.

\section{Dispersal of $S$. groenlandica}

Large-scale dispersal of kelps is generally thought to have originally occurred from the Pacific Ocean to the Atlantic Ocean (Adey et al. 2008). However, modern biogeographic distributions are dependent upon past dispersal and range distributions, which can be complicated by glacial periods that limit connections between populations (Van den Hoek \& Breeman 1989). Long distance dispersal likely occurs during the microscopic stages of algal life cycles, which can better tolerate high temperatures (Wiencke et al. 2006). But, this remains to be verified for S. groenlandica. Understanding the dispersal capabilities, distances, and population connectivity for S. groenlandica would help scientists identify potential mechanisms of colonization around the Svalbard Archipelago for this species. L digitata spores disperse around $2 \mathrm{~km}$ (Billot et al. 2003), which allows for relatively wide-spread dispersal compared to other algal species. Because of the morphological, anatomical, and reproductive similarities between $L$. digitata and S. groenlandica, it is reasonable to think that S. groenlandica spores also disperse distances similar to the magnitude of dispersal for L. digitata, However, this 
remains to be tested. S. groenlandica was observed at all sampling locations around the archipelago, while L. digitata was only identified in the area around Ny Ålesund.

There are a couple potential explanations for the observations of $S$. groenlandica around the Svalbard Archipelago: (1) recent dispersal of S. groenlandica from other areas surrounding the Arctic, (2) recent anthropogenic introduction of S. groenlandica to the archipelago, and (3) the species may have existed around the archipelago for a long time, but has been misidentified as $L$. digitata .

1. It may be that observations here of $S$. groenlandica in the different fjord systems resulted from a recent migration of a few S. groenlandica individuals to the archipelago from other areas of the Arctic Ocean. However, the drifting hypothesis requires that the migrants survive over long distances (over $1000 \mathrm{~km}$ between Svalbard and the coasts of Norway and Greenland), tolerate variable environmental conditions, recruit to a coastal subtidal area and then reproduce. Smaller islands, like Bjørnøya, may have acted as stepping stones for $S$. groenlandica colonization of the archipelago by recruits from areas surrounding the Arctic Ocean.

The lack of COI sequence diversity indicates that all S. groenlandica specimens collected around the archipelago come from a small group of recent colonization to the Svalbard Archipelago. Although, it must be considered that the COI gene region is a conserved, protein coding region and thus may not accurately represent the past dispersal history of this species around the Svalbard Archipelago. 
Most of the modern biogeographic changes around the Svalbard Archipelago and recolonizations by flora and fauna appear to be the result of transport via the Western Spitsbergen Current (WSC), which is an extension of the North Atlantic Current (NAC) (Sakshaug et al. 2009). The Western Spitsbergen current brings these warmer waters from the coast of Norway up the western coast of Spitsbergen and continues northward toward the Arctic Ocean. Relatively recent assessments of benthic algal distributions along the western coast of Norway have identified the presence of L. digitata based upon morphological traits (Lein et al. 1999). However, there have been no records for the presence of $S$. groenlandica along the western coast of Norway in either the Florø region on the southwest coast of Norway or in Trondheim farther north along the coast (Lein et al. 1999; Rueness et al. 2001; Lund 2014). Limited molecular data from this study and Lund (2014) have confirmed the presence of L. digitata in Trondheim, Norway, but did not identify S. groenlandica along the coast of Norway.

Based upon the general flow patterns of the Western Spitsbergen Current along the coast of Norway and the lack of $S$. groenlandica presence along that coast, it seems unlikely that $S$. groenlandica was transported recently to Svalbard from the coast of Norway.

2. The Svalbard Archipelago lies quite far from the nearest land mass and $S$. groenlandica migrants may have arrived to the island through anthropogenic methods such as, the collection of $S$. groenlandica in one area of the Arctic and later discarding reproductive individuals overboard, or through attachment to ships transiting between different areas of the Arctic. However, the widespread 
distribution of $S$. groenlandica around the archipelago does not seem to support the idea of recent recruitment to the archipelago since the 1996/1998, 2012/2013 (Fredriksen \& Kile 2012; Hop et al. 2012; Fredriksen et al. 2014) when biodiversity studies were conducted and did not identify the presence of $S$. groenlandica.

3. Another plausible explanation for the observation of S. groenlandica in our study and in Lund (2014) could be that S. groenlandica has existed around the Svalbard archipelago for quite a long time, but as a result of phenotypic plasticity S. groenlandica may be a cryptic species commonly misidentified as L. digitata (McDevit \& Saunders 2010). McDevit \& Saunders (2010) showed that phenotypically these two species from different genera can look very similar and can be incredibly difficult to distinguish in situ.

However, to properly identify whether $S$. groenlandica has been present around the archipelago for a long period of time, DNA barcoding of previously collected $L$. digitata specimens or algal tissue samples from the archipelago could be conducted to confirm the species identification of the specimens. If $S$. groenlandica has been present around the archipelago since Arctic kelp forest studies began in the 1990's, perhaps some of the research previously on $L$. digitata around the Svalbard Archipelago may have actually been performed on $S$. groenlandica and we as a science community may possess much more information regarding the distribution and ecophysiology of S. groenlandica than we know. 


\section{Conclusions}

In the last decade, there has been extensive work re-organizing the phylogenetic relationships of the Laminariales order (Yoon et al. 2001; Tai et al. 2001; Lane et al. 2006, 2007; McDevit \& Saunders 2009) based on molecular data. Molecular phylogenetic analysis based upon plastid RuBisCo, nuclear larger subunit (LSU) rDNA, nuclear ITS and mitochondrial nad6 sequences for the ALL (Alariaceae, Laminariaceae, and Lessoniaceae) families suggested, among many things, a split of the genus Laminaria Lamouroux 1813. These researchers resurrected the genus Saccharina Stackhouse 1809 for the clade of Laminaria sp. that did not cluster with the genus type L. digitata (Hudson) J.V. Lamouroux. Thus, separating the Saccharina genus of species from the Laminaria genus (McDevit \& Saunders 2010).

L. digitata and S. groenlandica functionally fill the same ecological role, but it is important for researchers to have the ability to accurately distinguish between these two algal species, especially when trying to assess biogeographic range shifts and biodiversity changes associated with climate change in the Arctic. L. digitata can be difficult to differentiate from S. groenlandica, especially due to phenotypic plasticity exhibited in the coastal environments of Svalbard. While the presence/absence of mucilage ducts in different tissues of the sporophyte, can differentiate between species, this is a difficult phenotypic characteristic to utilize during field collections and subtidal biodiversity studies. But, it should be common practice to collect a small tissue sample from each specimen, which can then be used for DNA barcoding and species verification. DNA barcoding should be used in conjunction with morphological characteristics to identify 
species (Schander \& Willassen 2005), and develop an understanding of biodiversity and abundances of various species.

This work, in addition to Lund (2014), expands our knowledge of the biogeographic distribution of $S$. groenlandica around the Arctic Ocean. Additional collection of specimens and sequence data are needed to truly understand how this new species arrived to the Svalbard Archipelago. Did this species disperse recently from other areas of the Arctic Ocean or has this species existed in this area of the Arctic for a long time? Population genetics may provide further evidence of how S. groenlandica arrived to the Svalbard Archipelago. In addition, more studies should be conducted to assess the expression of different morphotypes of the $S$. groenlandica and L. digitata and the reliability of using morphological features for species identification within the different fjord systems around the Svalbard Archipelago. 


\section{REFERENCES}

1. Adey W.H., Lindstrom S.C., Hommersand M.H. \& Muller K.M. 2008. The biogeographic origin of arctic endemic seaweeds: A thermogeographic view. Journal of Phycology 44:1384-1394.

2. Applied Biosystems. 2009. DNA Sequencing by Capillary Electrophoresis: Applied Biosystems Chemistry Guide. $2^{\text {nd }}$ Edition. Pgs 2-15

3. Balloux F. \& LugOn-Moulin N. 2002. The estimation of population differentiation with microsatellite markers. Molecular Ecology 11: 155-165

4. Berge J., Johnsen G., Nilsen F., Gulliksen B. \& Slagstad D. 2005. Ocean temperature oscillation enables reappearance of blue mussels Mytilus edulis in Svalbard after a 1000 year absence. Marine Ecology Progress Series 303: $167-175$

5. Berge J., Renaud P.E., Eiane K., Gulliksen B., Cottier F.R., Varpe O. \& Brattegard T. 2009. Changes in the decapod fauna of an Arctic fjord during the last 100 years (1908-2007). Polar Biology 32:953-961

6. Beuchel F., GulliKsen B. \& CARroll M.L. 2006. Long-term patterns of rocky bottom macrobenthic community structure in an Arctic fjord (Kongsfjorden, Svalbard) in relation to climate variability (1983-2003). Journal of Marine Systems 63:35-48

7. Beuchel F., Primicerio R., Lønne O.L., Gulliksen B. \& Birkely S. 2010. Counting and measuring epibenthic organisms from digital photographs: A semiautomated approach. Limnology and Oceanography: Methods: 229-240 
8. Billot C., Engel C.R., Rousvoal S., Kloareg B. \& Valero M. 2003. Current patterns, habitat discontinuities and population genetic structure: the case of the kelp Laminaria digitata in the English Channel. Marine Ecology Progress Series 253: 111-121

9. Billot C., Rousvoal S., Estoup A., Epplen J.T., Saumitou-Laprade P., VALERO M. \& KLOAREG B. 1998. Isolation and characterization of microsatellite markers in the nuclear genome of the brown alga Laminaria digitata (Phaeophyceae). Molecular Ecology 7: 1771-1788

10. Bolton J.J. 2010. The biogeography of kelps (Laminariales, Phaeophyceae): a global analysis with new insights from recent advances in molecular phylogenetics. Helgoland Marine Research 64: 263-279.

11. Boo S.M., Lee W.J., Yoon H.S., Kato A. \& Kawai H. 1999. Molecular phylogeny of Laminariales (Phaeophyceae) inferred from small subunit ribosomal DNA sequences. Phycological Research 47: 109-114

12. BRIGGS J. 1995. Global Biogeography. Elsevier, Amsterdam, 452 pp.

13. BRIGGS J. 2003. Marine centers of origin as evolutionary engines. Journal of Biogeography 30: 1-18

14. Carmack E.C., Barber D.G., Christensen J., MacDonald R., Rudels B. \& SAKSHAUG E. 2006. Climate variability and physical forcing of the food webs and the carbon budget on panarctic shelves. Progress in Oceanography 71 (24): $145-181$ 
15. Clarke D.L. 1990. Arctic Ocean ice cover; geologic history and climatic significance. In: The Arctic Ocean region (Ed. by Grantz A., Johnson L., \& Sweeney J.L.). Geological Society of America, Boulder, Co, pp 53-62

16. Darriba D., Taboada G.L., Doallo R. \& Posada D. 2012. jModelTest 2: more models, new heuristics and parallel computing. Nature Methods 9(8), 772.

17. Dickson R.R., Meincke J., Vassie I., Jungclaus J. \& Osterhus S. 1999. Possible predictability in overflow from the Denmark Strait. Nature 397: 243246

18. DRING M.J. 1982. The Biology of Marine Plants. Cambridge, England: The Press Syndicate of the University of Cambridge.

19. DRUEHL L. 1968. Taxonomy and distribution of northeast Pacific species of Laminaria. Canadian Journal of Botany 46:539-547

20. DRUEHL L. 1970. The pattern of Laminariales distribution in the northeast Pacific. Phycologia 9(3/4): 237-247

21. DRUehl L.D., CABOt E.L., \& LLOYD K.E. 1987. Seasonal growth of Laminaria groenlandica as a function of plant age. Canadian Journal of Botany 65: 1599-1604

22. DunTon K.H. 1992. Arctic biogeography: the paradox of the marine benthic fauna and flora. Trends in Ecology and Evolution 7: 183-189

23. European Molecular Biology Laboratory-European Bioinformatics Institute (EMBL-EBI). 2007. Clustal W and Clustal X version 2.0. Bioinformatics (Oxford, England) 23 (21): 2947-8 
24. Feliner G.N. \& Rossello J.A. 2007. Better the devil you know? Guidelines for insightful utilization of nrDNA ITS in species-level evolutionary studies in plants. Molecular Phylogenetics and Evolution 44:911-919

25. FREDRIKSEN S. \& KILE M.R. 2012. The algal vegetation in the outer part of Isfjorden, Spitsbergen: revisiting Per Svendsen's sites 50 years later. Polar Research 31: 17538. DOI: 10.3402/polar.v31i0.17538

26. FREDRIKSEN S., BARTSCH I. \& WieNCKE C. 2014. New additions to the benthic marine flora of Kongsfjorden, western Svalbard, and comparison between 1996/1998 and 2012/2013. Botanica Marina 57(3): 203-216

27. Graham L.E., Graham J.M., \& WiLcox L.W. 2009. Algae. $2^{\text {nd }}$ ed. San Francisco (CA): Pearson Education Inc.

28. Grantz A., Johnson L., \& Sweeney L. 1990. The Geology of North America Vol. L. The Arctic Ocean. Geological Society of America, Boulder, Co. 644 pp.

29. GuINDON S. \& GASCUEL O. 2003. A simple, fast and accurate method to estimate large phylogenies by maximum-likelihood. Systematic Biology 52: 696-704.

30. GUIRY M.D \& GUIRY G.M. 2009. AlgaeBase. Worldwide electronic publication, National University of Ireland, Galway. https://www.algaebase.org; searched June 2014

31. Gulliksen B., Palerun R., Brattegard T. \& Sneli J. 1999. Distribution of marine benthic macro-organisms at Svalbard (including Bear Island) and Jan Mayen. Research Report for Directorate for Nature Management 
32. Hanelt D., Tug H., Bischof K., Gross C., Lippert H., Sawall T., Karsten U. \& WIENCKE C. 2001. Light regime in an Arctic fjord: a study related to stratospheric ozone depletion as a basis for determination of UV effects on algal growth. Marine Biology 138: 649-658

33. Hoek C. VAn Den \& Breeman A.M. 1989. Seaweed biogeography in the North Atlantic: where are we? In: Evolutionary biogeography of the marine algae of the North Atlantic (Ed. by D.J. Garbary \& G.R. South). NATO ASI Series, Vol. G 22, Springer- Verlag, Berlin, Heidelberg pp 75-86

34. Hop H., Pearson T., Hegseth E.N., Kovacs K.M, Wiencke C., Kwasniewski S., Eiane K., Mehlun F., Gulliksen B., Wlodarska-Kowalczuk M., Lydersen C., Weslawski J.M., Cochrane S., Gabrielsen G.W., Leakey R., LønNe O.J., ZAJACZKowsKi M., FALK-PETERSEN S., KendALl M., WANGBerg S., Bischof K., Voronhov A.Y., Kovaltchouk N.A., Wiktor J., Poltermann M., di Prisco G., Papucci C. \& Gerland S. 2002. The marine ecosystem of Kongsfjord, Svalbard. Polar Research 21(1): 167-208

35. Hop H., Wiencke C., Vögele B. \& Kovaltchouk N.A. 2012. Species composition, zonation, and biomass of marine benthic macroalgae in Kongsfjorden, Svalbard. Botanica Marina 55: 399-414

36. JoHN D.M. 1994. Alteration of generation in algae: Its complexity, maintenance, and evolution. Biological Review 69:275-291

37. JoHNSON J.B. \& OMLAND K.S. 2004. Model selection in ecology and evolution. Trends in Ecology and Evolution 19(2): 101-108 
38. KAWAI H., SASAKI H. 2000. Molecular phylogeny of the brown algal genera Akkesiphycus and Halosiphon (Laminariales), resulting in the circumscription of the new families Akkesiphycaceae and Halosiphonaceae. Phycologia $39: 416-428$

39. KEDRA M. 2008. Interannual changes in biodiversity of the Arctic soft bottom macrobenthos in Kongsfjorden, Spitsbergen. PhD thesis, Institute of Oceanology Polish Academy of Sciences, Sopot

40. Kedra M., Wlodarska-Kowalczuk M., WesLawski JM. 2010. Decadal Changes in a macrobenthic soft bottom community structure in a high Arctic fjord (Kongsfjorden, Svalbard). Polar Biology 33: 1-11

41. KemP B.M., \& Smith D.G. 2005. Use of bleach to eliminate contaminating DNA from the surface of bones and teeth. Forensic Science International 154: 5361

42. KJellman F.R. 1883. The algae of the Arctic Sea. Journal of Phycology 31: 181199

43. Kraemer G.P. \& Chapman D.J. 1991. Biomechanics and alginic acid composition during hydrodynamic adaptation by Egregia menziesii (Phaeophyta) juveniles. Journal of Phycology 27: 47-53

44. LANE C.E., LindSTROM S.C., \& SAUNDERS G.W. 2007. A molecular assessment of northeast Pacific Alaria species (Laminariales, Phaeophyceae) with reference to the utility of DNA barcoding. Molecular Phylogenetics and Evolution $44: 634-648$ 
45. Lane C.E., Mayes C., Druehl L.D. \& Saunders G.W. 2006. A multi-gene molecular investigation of the kelp (Laminariales, Phaeophyceae) supports substantial taxonomic re-organization. Journal of Phycology 42: 493-512

46. Laturnus F. \& G. MehrTens. 2004. Marine macroalgae from Kongsfjorden, Arctic- Comparison of halogenating activity and release of volatile organobromine compounds. In: The coastal ecosystem of Kongsfjord, Svalbard. Synopsis of biological research performed at the Koldewey Station in the years 1991-2003 (Ed. by C. Wiencke). Ber. PolarForsch. Meersforsch. 492. ISSN 1618-3193

47. Leclerc M.C., Barriel V., Lectointre G. \& De Reviers B. 1998. Low Divergence in rDNA ITS Sequences among five species of Fucus (Phaeophyceae) suggests a very recent radiation. Journal of Molecular Evolution 46:115-120

48. LEIN T.E., BRUNTSE G. \& NIELSEN R. 1999. New records of benthic marine algae for Norway, with notes on some rare species from the Florø district, western Norway. Sarsia 84:39-53

49. LiPPERT H., IKEN K., RACHOR E. \& WienCKe C. 2001. Macrofauna associated with macroalgae in the Kongsfjord (Spitsbergen). Polar Biology 24: 512-522

50. LUND L. 2014. Morphological diversity in Laminaria digitata: different species or different phenotypes. Masters Thesis, Norwegian University of Science and Technology 
51. LÜNING K. 1979. Growth Strategies of three Laminaria species (Phaeophyceae) inhabiting different depth zones in the sublittoral region of Helgoland (North Sea). Marine Ecology Progress Series 1: 195-207

52. LÜNING K. 1988. Photoperiodic control of sorus formation in the brown alga Laminaria saccharina. Marine Ecology Progress Series 45: 137-144

53. LÜNING K. \& TOM DIECK I. 1989. Environmental triggers in algal sensitivity. Botanica Marina 32: 389-397

54. LÜNING K. 1990. Seaweeds: their environment, biogeography and ecophysiology. New York, Chichester, Brisbane, Toronto, Singapore: John Wiley, Sons, Inc. $527 \mathrm{pp}$.

55. MADDISON D.R. \& MADDISON W.P. 2005. MacClade 4: Analysis of phylogeny and character evolution. Version 4.08a. http://macclade.org

56. McDevit D.C. \& SAunders G.W. 2009. On the Utility of DNA barcoding for species differentiation among brown macroalgae (Phaeophyceae) including a novel extraction protocol. Phycological Research 57: 131-141

57. McDevit D.C. \& SAunders G.W. 2010. A DNA barcode examination of the Laminariaceae (Phaeophyceae) in Canada reveals novel biogeographical and evolutionary insights. Phycologia 49: 235-248

58. Moe R.L. \& Silva P.C. 1977. Antarctic marine flora: uniquely devoid of kelps. Science 196: 1206-1208

59. Moline M.A., Karnovsky N.J., Brown Z., Divoky G.J., FraZer T.K., Jacoby C.A., Torres J.J. \& Fraser W.R. 2008. High Latitude Changes in Ice 
Dynamics and Their Impact on Polar Marine Ecosystems. Annals of the New York Academy of Sciences 1134: 267-319

60. MÜLler D.G., MaIer I. \& Gassmann G. 1985. Survey on sexual pheromone specificity in Laminariales (Phaeophyceae). Phycologia 24 (4): 475-477

61. Nei M. \& Kumar S. 2000. Molecular Evolution and Phylogenetics. Oxford University Press. Edition 1.

62. Rambaut A. 2006. FigTree v1.4. Updated October 8, 2012

63. Renaud P.E., CARRoll, M.L. \& Ambrose W.G. 2008. Effects of global warming on Arctic sea-floor communities and its consequences for higher trophic levels. In: Impacts of Global Warming on Polar Ecosystems (Ed. by C.M. Duarte).

64. Roleda M., Clayton M.N. \& WiencKe C. 2006. Screening capacity of UVabsorbing compounds in spores of Arctic Laminariales. Journal of Experimental Marine Biology and Ecology 338: 123-133

65. Roleda M.Y., Wiencke C., Hanelt D., van De Poll W.H. \& Gruber A. 2005. Sensitivity of Laminariales zoospores from Helgoland (North Sea) to ultraviolet and photosynthetically active radiation: implications for depth distribution and seasonal reproduction. Plant, Cell and Environment 28:466479

66. Rosenvinge L.K. 1898. Om algevegetationen ved Grønlands kyster. Oversigt over Grønlands havalger. (The algal vegetation from the coasts of Greenland. Overview of the marine algae from Greenland.) Meddelser om Grønland 20. Copenhagen: C.A. Reitzel. 
67. Rueness J., Brattegard T., Lein T.E., Küfner R., Pedersen A. \& Sørlie A.C. 2001. Distribution of marine, benthic macroorganisms in Norway: A tabulated catalogue. Directorate for Nature Management. Trondheim, Norway

68. Sakshaug E., Johnsen G. \& Kovacs K. 2009. Ecosystem Barents Sea. Trondheim (Norway): Tapir Academic Press.

69. SAUNDERS G.W. 2005. Applying DNA barcoding to red macroalgae: a preliminary appraisal holds promise for future applications. Philosophical Transaction of the Royal Society of Biological Sciences 360: 1879-1888

70. SCHANDER C. \& WiLlaSSEN E. 2005. What can biological barcoding do for marine biology?. Marine Biology Research 1(1): 79-83

71. SCHiEL D.R. \& Foster M.S. 2006. The Population Biology of Large Brown Seaweeds: Ecological Consequences of Multiphase Life Histories in Dynamic Coastal Environments. Annual Review of Ecology, Evolution, and Systematics 37: $343-372$

72. Setchell W.A. \& GardneR N.L. 1925. The marine algae of the Pacific Coast of North America. Part III. Melanophyceae. University of California (Berkeley) Publications in Botany 8: 383-898

73. Svendsen H., Beszczynska-Møller A., Hagen J.O., Lefauconnier B., TVERBERG V. \& GERLAND S. 2002. The physical environment of Kongsfjorden-Krossfjorden, an Arctic fjord system in Svalbard. Polar Research 21:133-166

74. SVENDSEN P. 1959. The algal vegetation of Spitsbergen. A survey of the marine algal flora of the outer part of Isfjorden. Norsk Polarinst Skrifter 116: 1-49 
75. SwOFFoRD D.L. 2002. PAUP*. Phylogenetic Analysis Using Parsimony (*and Other Methods). Version 4. Sinauer Associates, Sunderland, Massachusetts

76. TAi V., Lindstrom S.C. \& SAunders G.W. 2001. Phylogeny of the Dumontiaceae (Gigartinales, Rhodophyta) and associated families based on SSU rDNA and Internal Transcribed Spacer sequence data. Journal of Phycology 37: 184-196

77. United Nations Food and Agriculture Fisheries Department (UN FAO Fisheries Department). 2004. The State of World Fisheries and Aquaculture Report. Rome, Italy.

78. Van Alstyne K.L., McCarthy J., Hustead C.L. \& Duggins D.O. 1999.

Geographic variation in polyphenolic levels of North-eastern Pacific kelps and rockweeds. Marine Biology 133: 371-379

79. VINOGRAdOVA K.L. 1995. The checklist of marine algae from Spitsbergen. Botanicheskii Zhurnal 80: 50-61

80. Wassman P., Duarte C.M, Agusti S. \& SeJR, M.K. 2010. Footprints of climate change in the Arctic marine ecosystem. Global Climate Change Biology 17(2):1235-1249

81. Weslawski J.M., Kendall M.A., Wlodarska-Kowalczuk M., Iken K., Kodra M., LegezynsKa J. \& SeJR M.K. 2011. Climate Change effects on Arctic fjord and coastal macrobenthic diversity-observations and predictions. Marine Biology 41:71-8 
82. WesLAwski J.M., WikTOR J., ZAJACZKOWSKi M. \& SwerPel S. 1993. Intertidal zone of Svalbard. 1. Macroorganisms distribution and biomass. Polar Biology 13: 73-79.

83. Weslawski J.M., ZaJAczkowski M., Wiktor J. \& Szymelfenig M. 1997. Intertidal zone of Svalbard. 3. Littoral of a subarctic, oceanic island: Bjørnøya. Polar Biology 18:45-52

84. WIENCKE C. 2004. The coastal ecosystem of Kongsfjorden, Svalbard. Synopsis of biological research performed at the Koldewey Station in the years 19912003. Berichte zur Polar- und Meeresforschung 492:1-244

85. Wiencke C., Clayton M.N., Gomez I., Iken K., Luder U.H., Amsler C.D., Karsten U., Hanelt D., Bischof K. \& Dunton K. 2006. Life strategy, ecophysiology and ecology of seaweeds in polar waters. Review of Environmental Science and Biotechnology. DOI 10.1007/s11157-006-9106z

86. Wiencke C., Vögele B., Kovaltchouk N.A. \& Hop H. 2004. Species composition and zonation of marine benthic macroalgae at Hansneset in Kongsfjorden, Svalbard. Ber Polarforsch Meeresforsch 492:55-62

87. WILCE R.T. 1965. Studies on the genus Laminaria. 3. A revision of the north Atlantic species of the Simplices section of Laminaria. Botanica Gothenburg 3: $247-256$

88. WILCE R.T. 1990. Role of the Arctic Ocean as a bridge between the Atlantic and Pacific Oceans: fact and hypothesis. In: Evolutionary biogeography of the marine algae of the North Atlantic (Ed. by D.J. Garbary \& G.R. South). 
Springer-Verlag Berlin, Heidelberg, New York, London, Paris, Tokyo, Hong Kong, Barcelona pp 323-348

89. WILCE R.T. 1994. The Arctic subtidal as habitat for macrophytes. In: Seaweed ecology and physiology (Ed. by C.S. Lobban \& P.J. Harrison). Cambridge University Press, Cambridge, pp 89-92

90. WlodarsKa-KOWALCZUK M., KUKLINKSi P., RONOWiCZ M., LEGEZYNSKA J. \& Gromisz S. 2009. Assessing species richness of macrofauna associated with macroalgae in Arctic kelp forests (Hornsund, Svalbard). Polar Biology 32: $897-905$

91. Yoon H.S., Lee J.Y., Sung M.B. \& Bhattacharya D. 2001. Phylogeny of Alariaceae, Laminariaceae, and Lessoniaceae (Phaeophyceae) based on plastid-encoded RuBisCo spacer and nuclear-encoded ITS sequence comparisons. Molecular Phylogenetics and Evolution 21(2): 231-243

92. ZeMKe-White W.L \& OHNo M. 1999. World seaweed utilization: An end-ofcentury summary. Journal of Applied Phycology 11: 369-376 
APPENDICES 


\section{A. TABLES}

Table 1. Sampling locations, collection dates, Lat/Lon (degrees minutes seconds), and number of specimens collected subtidally at each sample site.

\begin{tabular}{|c|c|c|c|}
\hline $\begin{array}{l}\text { Sampling Location, } \\
\text { Fjord Name }\end{array}$ & $\begin{array}{l}\text { Collection } \\
\text { date }\end{array}$ & $\begin{array}{l}\text { Lat/Lon } \\
\text { (Degrees minutes } \\
\text { seconds) }\end{array}$ & $\begin{array}{l}\text { Number of } \\
\text { Specimens } \\
\text { Collected }\end{array}$ \\
\hline Ny Ålesund, Kongsfjord & $9 / 09$ & $\begin{array}{l}78^{\circ} 55^{\prime} 42.68 " \mathrm{~N} \\
11^{\circ} 55^{\prime} 16.10^{\prime \prime} \mathrm{E}\end{array}$ & 26 \\
\hline $\begin{array}{l}\text { Tommeløya, } \\
\text { Hinlopen Strait }\end{array}$ & $8 / 29 / 09$ & $\begin{array}{l}79^{\circ} 33^{\prime} \mathrm{N} \\
18^{\circ} 44^{\prime} \mathrm{E}\end{array}$ & 34 \\
\hline Rossøya, Rijpfjord & $9 / 2 / 09$ & $\begin{array}{l}80^{\circ} 49^{\prime} \mathrm{N} \\
20^{\circ} 18^{\prime} \mathrm{E}\end{array}$ & 30 \\
\hline Sagaskjæret, Isfjord & $8 / 25 / 09$ & $\begin{array}{l}78^{\circ} 12^{\prime} 34.2^{\prime \prime} \mathrm{N} 13^{\circ} 56^{\prime} \\
29.0^{\prime \prime} \mathrm{E}\end{array}$ & 31 \\
\hline $\begin{array}{l}\text { Bjørndalen } \\
\text { (Fuglefjellet), Isfjord }\end{array}$ & $5 / 13 / 10$ & $\begin{array}{l}78^{\circ} 13^{\prime} 2.42^{\prime \prime} \mathrm{N} \\
15^{\circ} 15^{\prime} 30.42^{\prime \prime} \mathrm{E}\end{array}$ & 31 \\
\hline $\begin{array}{l}\text { Trondheim, } \\
\text { Trondheimsfjord }\end{array}$ & $7 / 5 / 10$ & $\begin{array}{l}63^{\circ} 26^{\prime} 28.53^{\prime \prime} \mathrm{N} \\
10^{\circ} 20^{\prime} 56.13^{\prime \prime} \mathrm{E}\end{array}$ & 30 \\
\hline $\begin{array}{l}\text { Smeerenburg, } \\
\text { Smeerenburgfjord }\end{array}$ & $9 / 09$ & $\begin{array}{l}79^{\circ} 42^{\prime} 28.66^{\prime \prime} \mathrm{N} \\
11^{\circ} 3^{\prime} 4.49^{\prime \prime} \mathrm{E}\end{array}$ & 31 \\
\hline $\begin{array}{l}\text { Tommeløya } \\
\text { (Tommelen)- } \\
\text { L. solidungula }\end{array}$ & $8 / 29 / 09$ & $\begin{array}{l}79^{\circ} 33^{\prime} \mathrm{N} \\
18^{\circ} 44^{\prime} \mathrm{E}\end{array}$ & 5 \\
\hline $\begin{array}{l}\text { North Wales- } \\
\text { L. digitata }\end{array}$ & - & - & 1 \\
\hline Total Number & & & 219 \\
\hline
\end{tabular}


Table 2. Measurements of morphological features collected on individuals $(\mathrm{n}=7)$ from the Tommeløya population $\left(79^{\circ} 33^{\prime} \mathrm{N}, 18^{\circ} 44^{\prime} \mathrm{E}\right)$ on August 29,2009 near the island of Tommelen in the Hinlopen Strait.

\begin{tabular}{|c|c|c|c|}
\hline Sample ID & $\begin{array}{l}\text { Thallus Length } \\
(\mathrm{cm})\end{array}$ & $\begin{array}{l}\text { Stipe Length } \\
(\mathrm{cm})\end{array}$ & $\begin{array}{l}\text { Haptera Diameter } \\
(\mathrm{cm})\end{array}$ \\
\hline Tommelen 01 & 35.5 & 14 & 5.6 \\
\hline Tommelen 02 & 29.3 & 8.4 & 5.3 \\
\hline Tommelen 03 & 31.5 & 3.7 & 4.0 \\
\hline Tommelen 04 & 45.5 & 3.7 & 5.5 \\
\hline Tommelen 05 & 40.5 & 11.8 & 7.3 \\
\hline Tommelen 06 & 29.0 & 5.5 & 8.5 \\
\hline Tommelen 07 & 35.5 & 4.9 & 8.5 \\
\hline Mean Length & 35.3 & 7.4 & 6.4 \\
\hline Standard Deviation (SD) & 6.1 & 4.1 & 1.7 \\
\hline Standard Error (SE) & 2.3 & 1.6 & 0.7 \\
\hline
\end{tabular}


Table 3. Matrix of actual pairwise nucleotide differences between all $L$. digitata and $S$. groenlandica specimens used in this analysis. Actual PAUP* outputs shown in Figs. 1418.

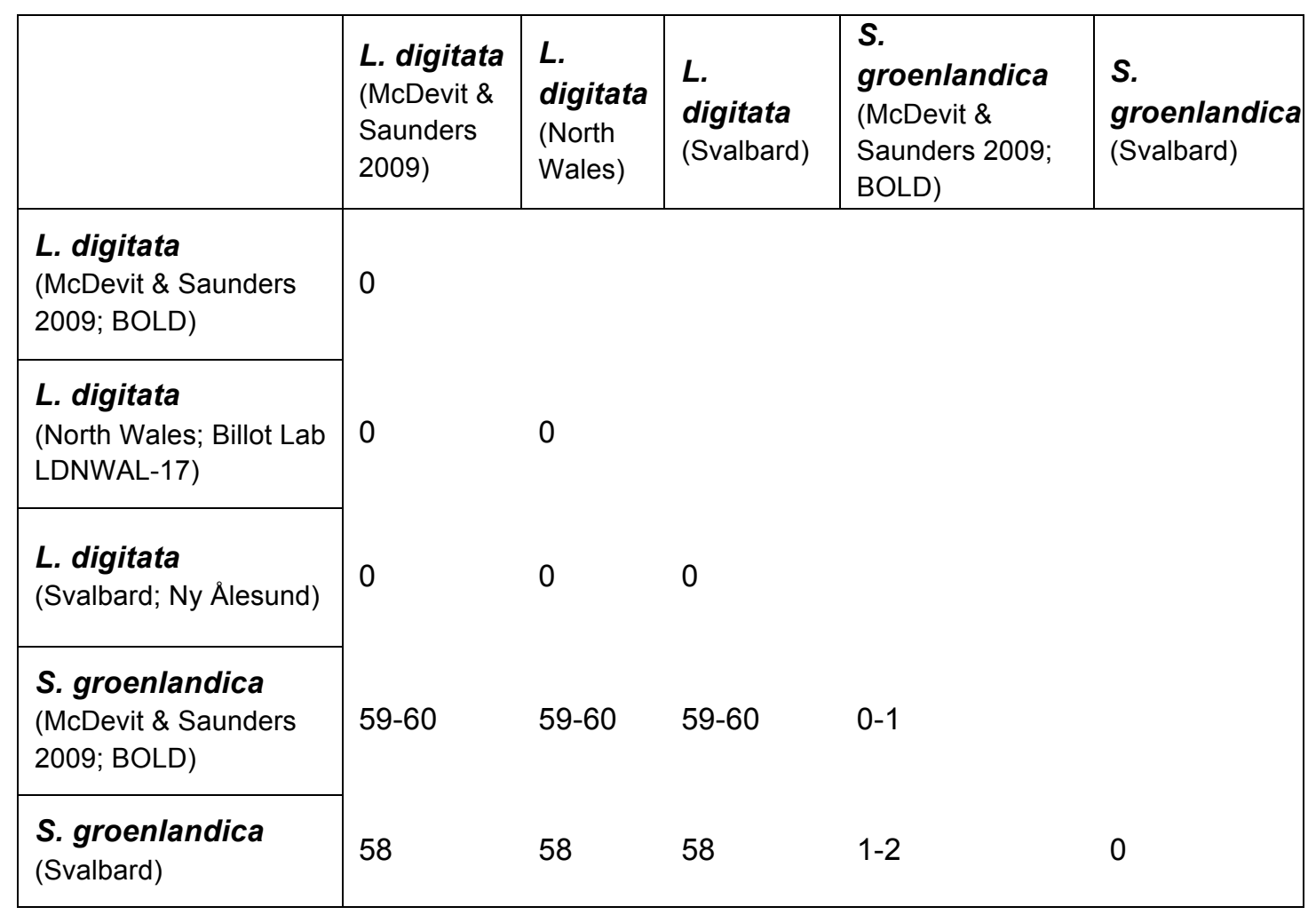


Table 4. The number of $L$. digitata and $S$. groenlandica species identified at each sampling location based upon DNA barcoding using the COI gene region. A total of 61 sequences from 59 specimens were used in the phylogenetic analysis.

\begin{tabular}{|c|c|c|c|c|}
\hline $\begin{array}{l}\text { Sample } \\
\text { Location }\end{array}$ & $\begin{array}{l}\text { Total number of } \\
\text { specimens with } \\
\text { full } \mathrm{COI} \\
\text { sequence }\end{array}$ & $\begin{array}{l}\text { Total number } \\
\text { L. digitata }\end{array}$ & $\begin{array}{l}\text { Total number } \\
\text { S. groenlandica }\end{array}$ & $\begin{array}{l}\text { Total number } \\
\text { L. solidungula }\end{array}$ \\
\hline Ny Ålesund & 7 & 2 & 5 & - \\
\hline Tommeløya & 11 & - & 10 & 1 \\
\hline Rossøya & 12 & - & 12 & - \\
\hline Sagaskjæret & 6 & - & 6 & - \\
\hline Bjørndalen & 10 & - & 10 & - \\
\hline Trondheim & 4 & 4 & - & - \\
\hline Smeerenburg & 8 & - & 8 & - \\
\hline North Wales & 1 & 1 & - & - \\
\hline Total & 59 & 7 & 51 & 1 \\
\hline
\end{tabular}




\section{B. FIGURES}

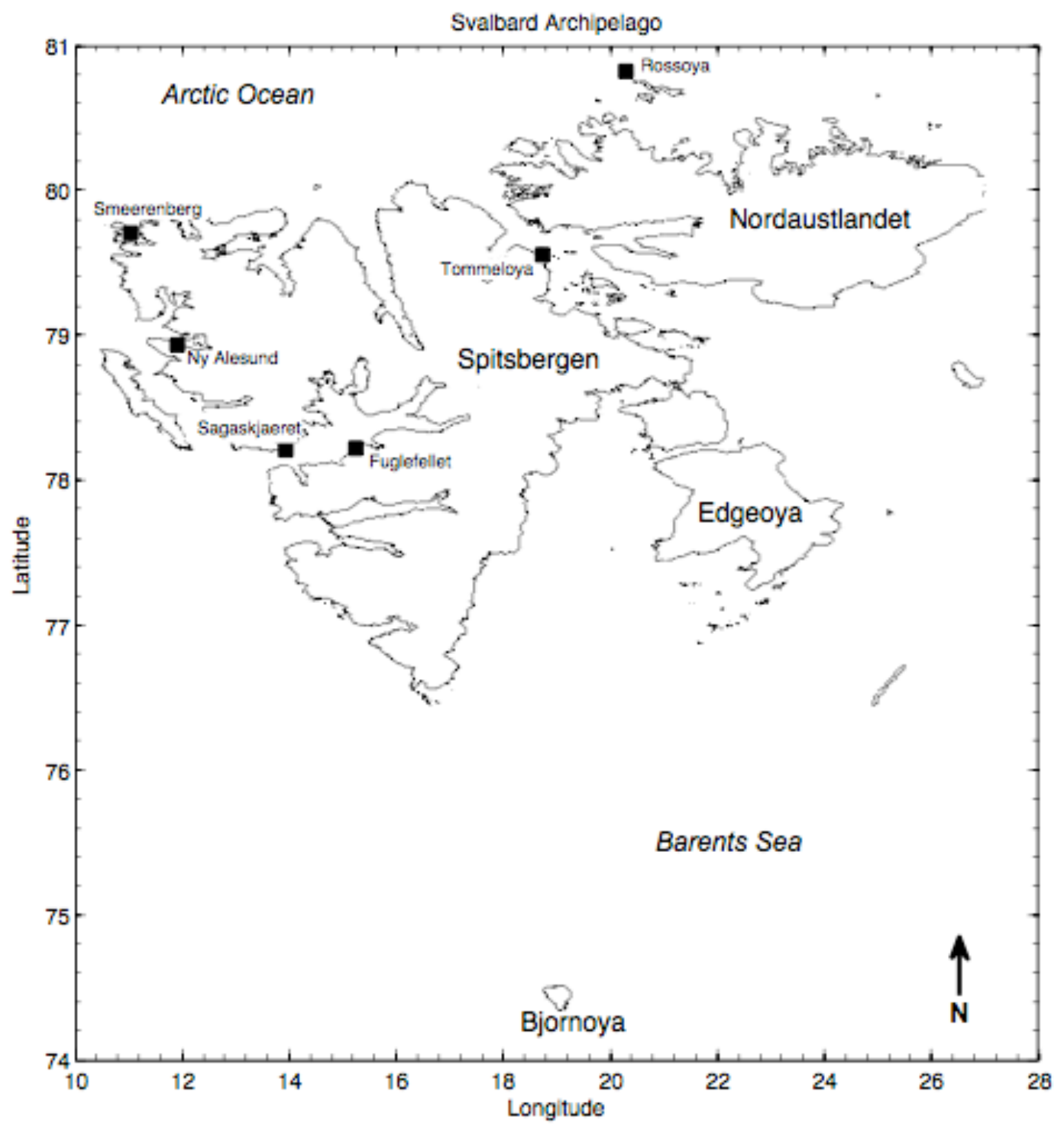

Figure 1. Map of Svalbard Archipelago and the sampling locations for this study. Samples collected in spring 2009 and fall 2010 aboard the R/V Jan Mayen. All six sampling sites around the Svalbard Archipelago are marked with black squares. The Trondheim sampling site, which is located on the coast of Norway, is not shown on this map. 

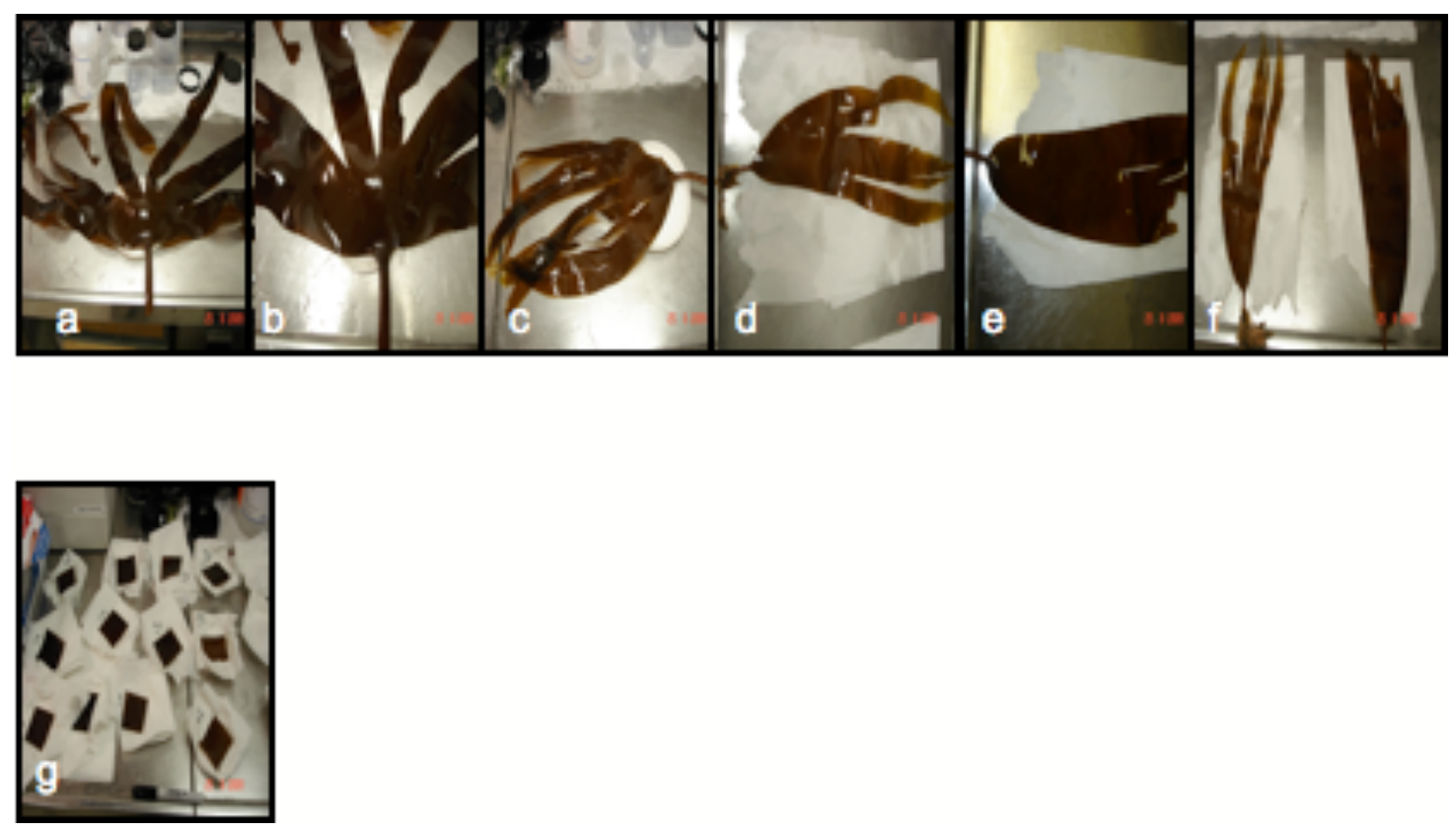

Figure 2. Specimens collected subtidally near the island of Sagaskjæret, Isfjord, Svalbard $\left(78^{\circ} 12^{\prime} 34.2^{\prime \prime} \mathrm{N}, 13^{\circ} 56^{\prime 29.0}\right.$ 'E) on August 25, 2009. Samples collected between 5-12 m depth. (a-f) illustrate the digitate and "strap-like" nature of the specimens collected around Sagaskjæret, near the mouth or outer portion of Isfjord,(g) samples of meristematic tissue collected from the transition zone between the blade and stipe from individual blades for specimens collected at this location. 

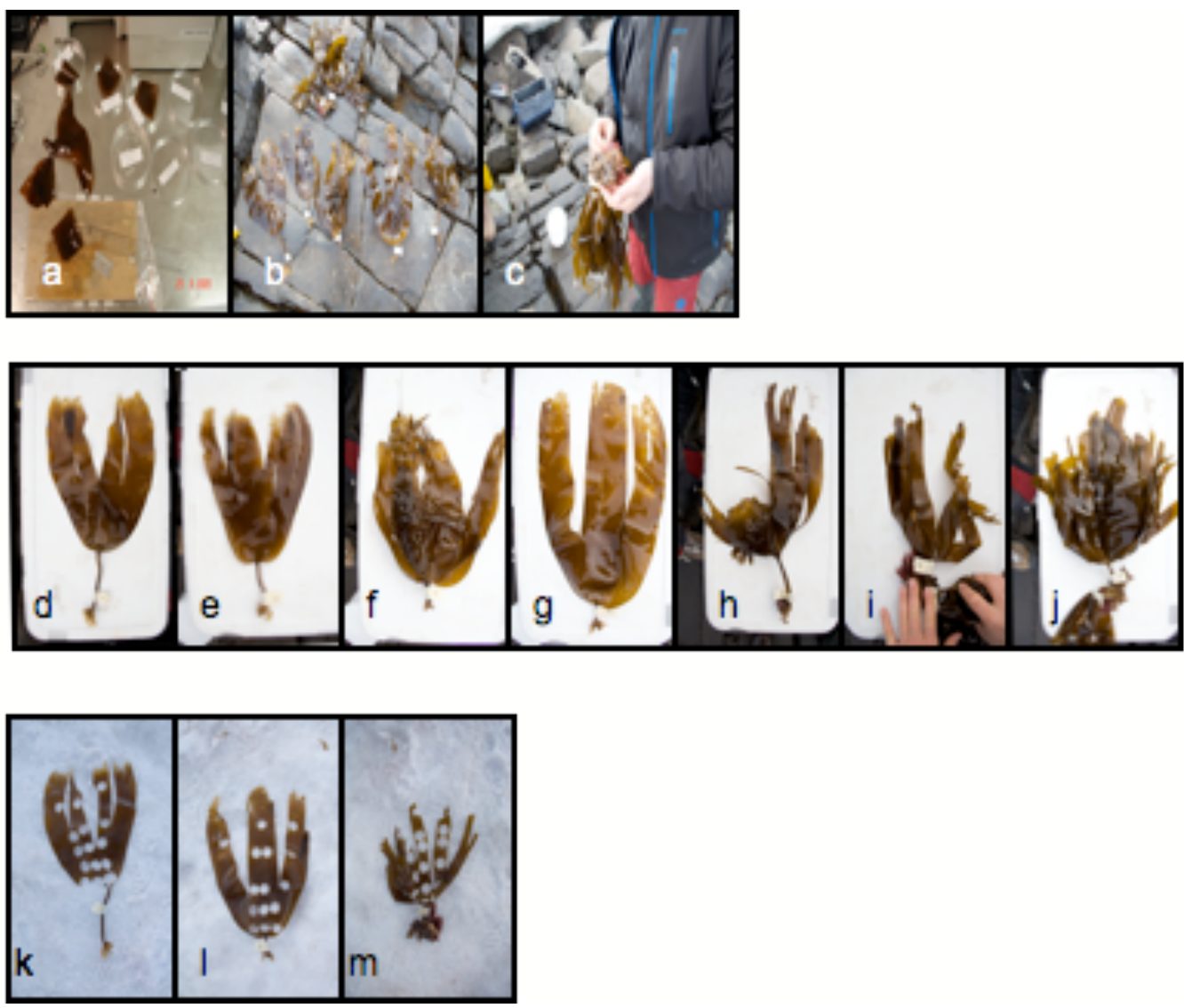

Figure 3. Specimens collected subtidally near the island of Tommeløya $\left(79^{\circ} 33^{\prime} \mathrm{N}, 18^{\circ}\right.$ 44'E), Hinlopen Strait on August 29, 2009 aboard the R/V Jan Mayen. Samples collected from depths between 3-5 meters. (a) processing and collection of $5 \mathrm{~cm}$ by $5 \mathrm{~cm}$ tissue samples, (b-c) photographs of different specimens (whole) collected, (d-i) Individual specimens numbered 1-7, (k) POC/PON samples collected from specimen 1, (1) POC/PON samples collected from specimen 4, and (m) POC/PON samples collected from specimen 6 . This population possessed a rather short stipe length to blade length. 

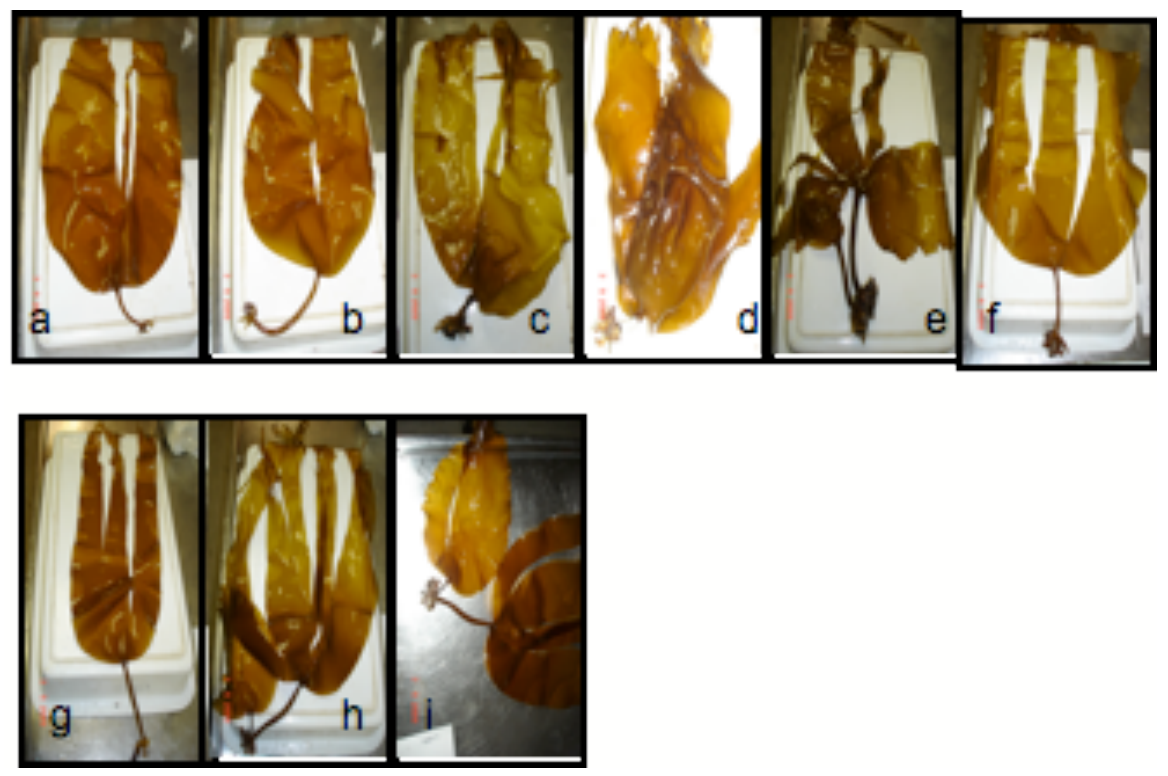

Figure 4. Specimens collected subtidally near the island of Rossøya $\left(80^{\circ} 49^{\prime} \mathrm{N}, 20^{\circ} 18^{\prime} \mathrm{E}\right)$. Samples collected by divers subtidally at around 10-15 m depth. Samples were numbered after harvesting tissues and most of the specimens brought up by divers only consisted of the meristematic region of the blade/stipe. (a-i) illustrate the variety of phenotypes present in the area, (d) specimen exhibiting distinct bullae present on the blade, which is a morphological trait more typically associated with a $S$. groenlandica than L. digitata. 

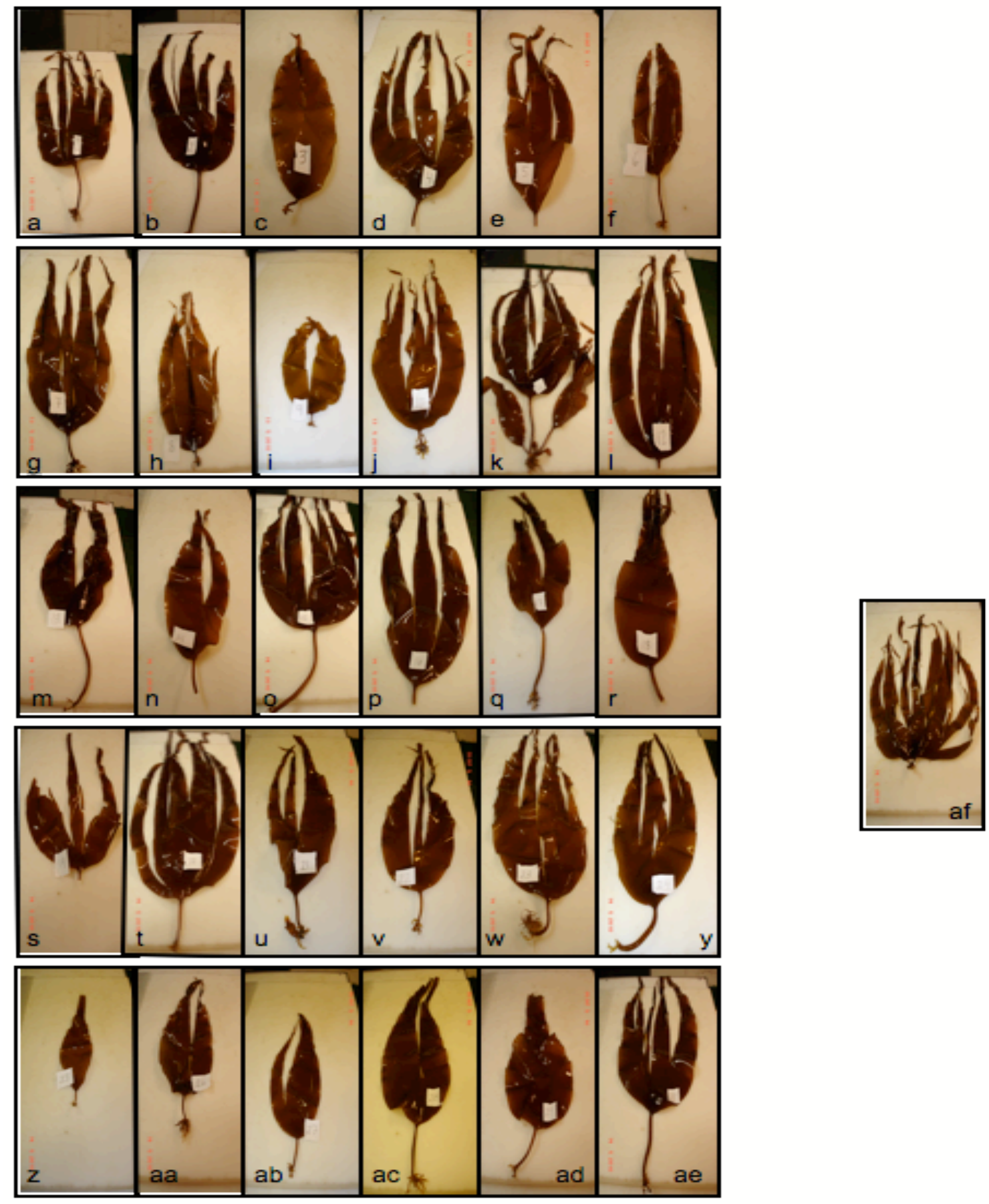

Figure 5. Specimens collected on May 13, 2010 offshore of Bjørndalen (Fuglefjellet), in Isfjord $\left(78^{\circ} 13^{\prime} 2.42^{\prime} \mathrm{N}, 15^{\circ} 15^{\prime} 30.42^{\prime} \mathrm{E}\right)$ on May 13,2010 . These specimens were collected subtidally on the opposite side of Isfjord from the Sagaskjæret population. 

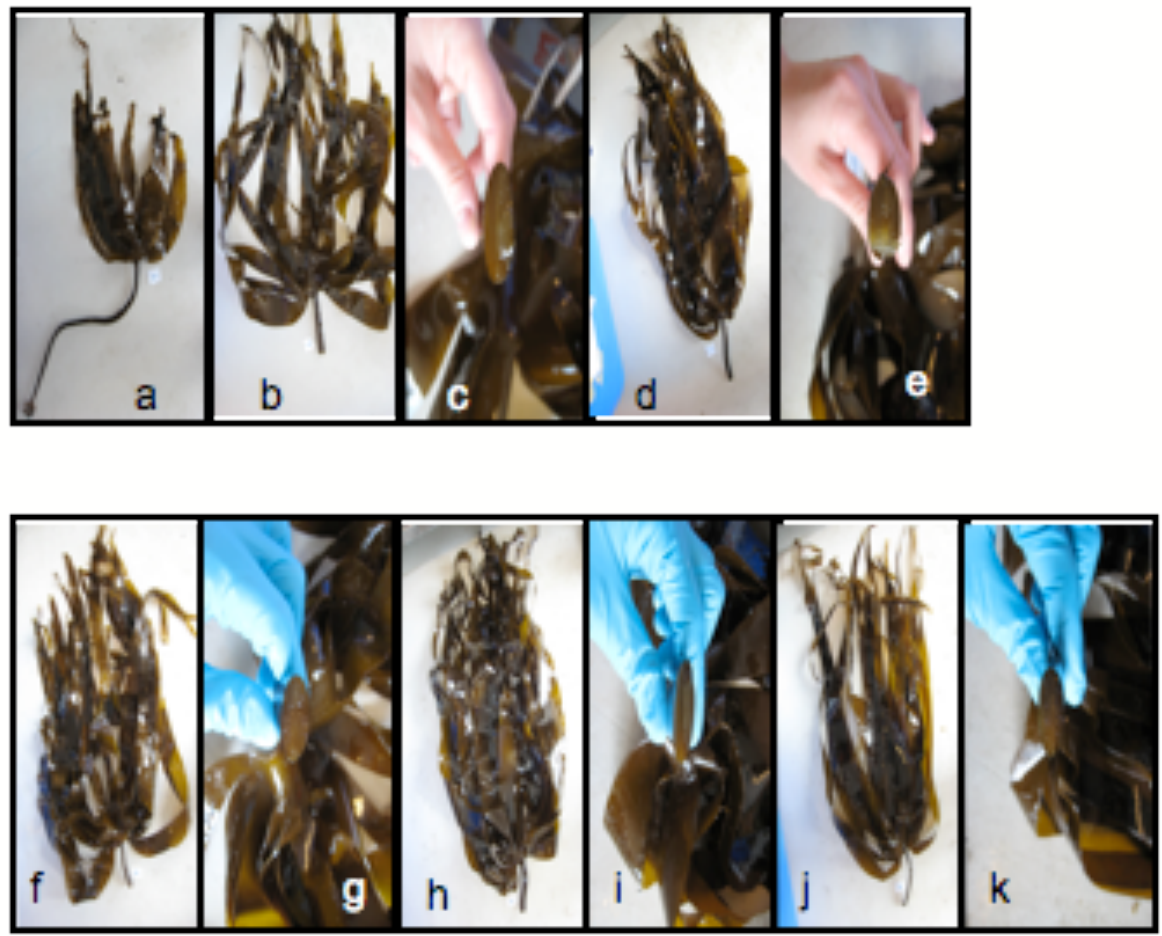

Figure 6. Specimens collected on July 5, 2010 near Trondheim Biological Station, Trondheimsfjord, Norway $\left(63^{\circ} 26^{\prime} 28.53^{\prime \prime N}, 10^{\circ} 20^{\prime} 56.13^{\prime \prime E}\right)$. Specimens collected subtidally and photos were taken of the first six samples. (a) specimen 1, (b-c) specimen 2 blade and cross-section (x-section), (d-e) specimen 3 blade and stipe $\mathrm{x}$-section, (f-g) specimen 4 blade and stipe $\mathrm{x}$-section, (h-i) specimen 5 blade and stipe $\mathrm{x}$-section, and (j-k) specimen 6 blade and stipe $\mathrm{x}$-section. These specimens were identified as L. digitata based upon DNA barcoding with the COI gene region. 


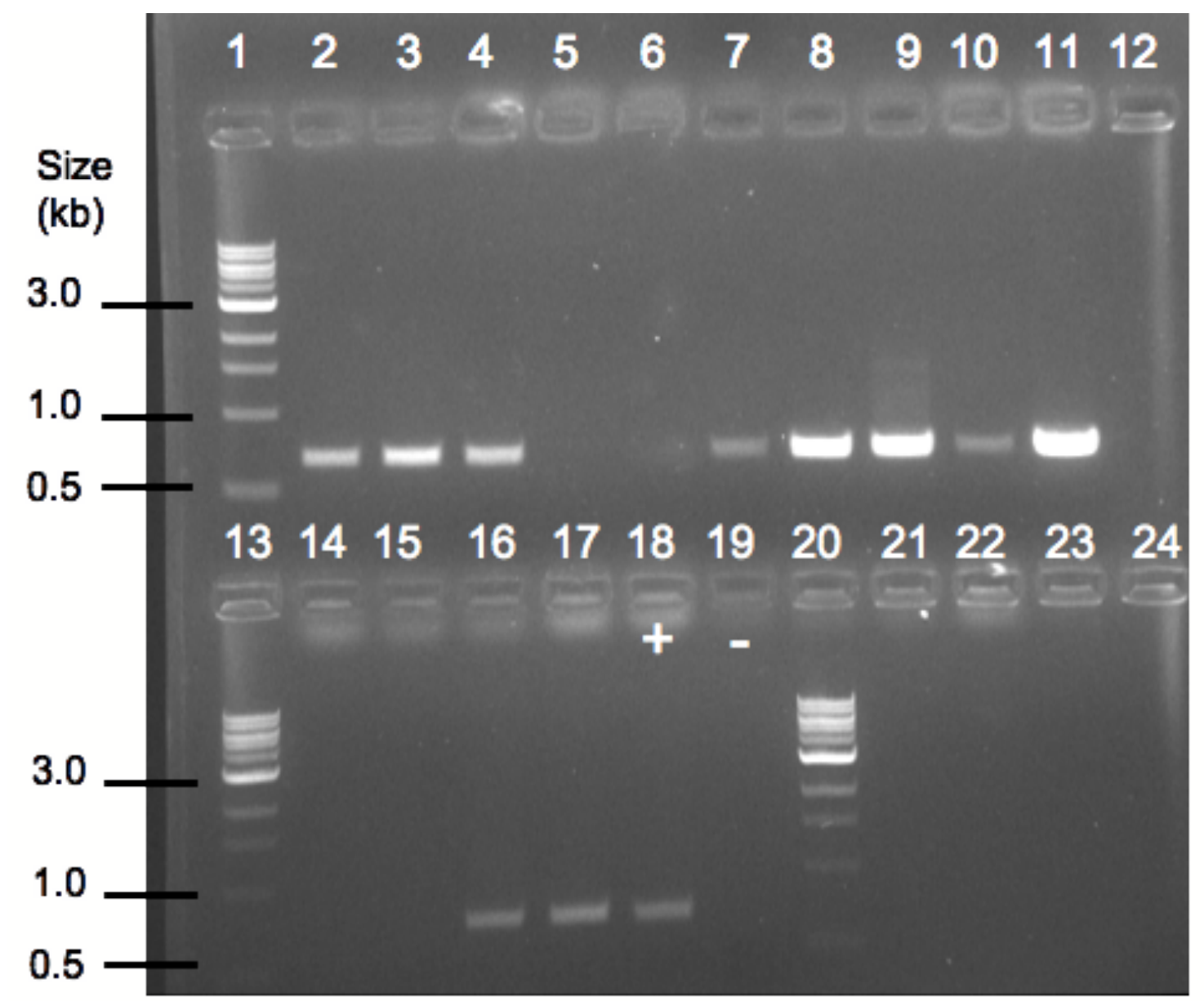

Figure 7. Gel electrophoresis (1.5\% agarose gel stained with EtBr) of cytochrome $c$ oxidase I (COI) PCR products from the Tommeløya, Ny Ålesund, and Rossøya populations compared with a $1 \mathrm{~kb}$ DNA ladder. Expected amplicon length of $658 \mathrm{bp}$ for all specimens. Lanes 2-12(2.T_22,3.T_23, 4.T_24, 5.T_26, 6.T_27, 7.T_28,8.T_29C, 9.Tommeloya \#1, 10.Tommeloya \#4, 11.NA_03a, 12.Empty) and Lanes 14-17 (14.Lsoli\#19, 15.Lsoli\#22, 16.Lsoli\#25, 17.R_10) correspond to COI sequences for Svalbard samples. Lane 18 shows the positive control (+) and Lane 19 shows the negative control (-). Lanes 21-24 were empty. 


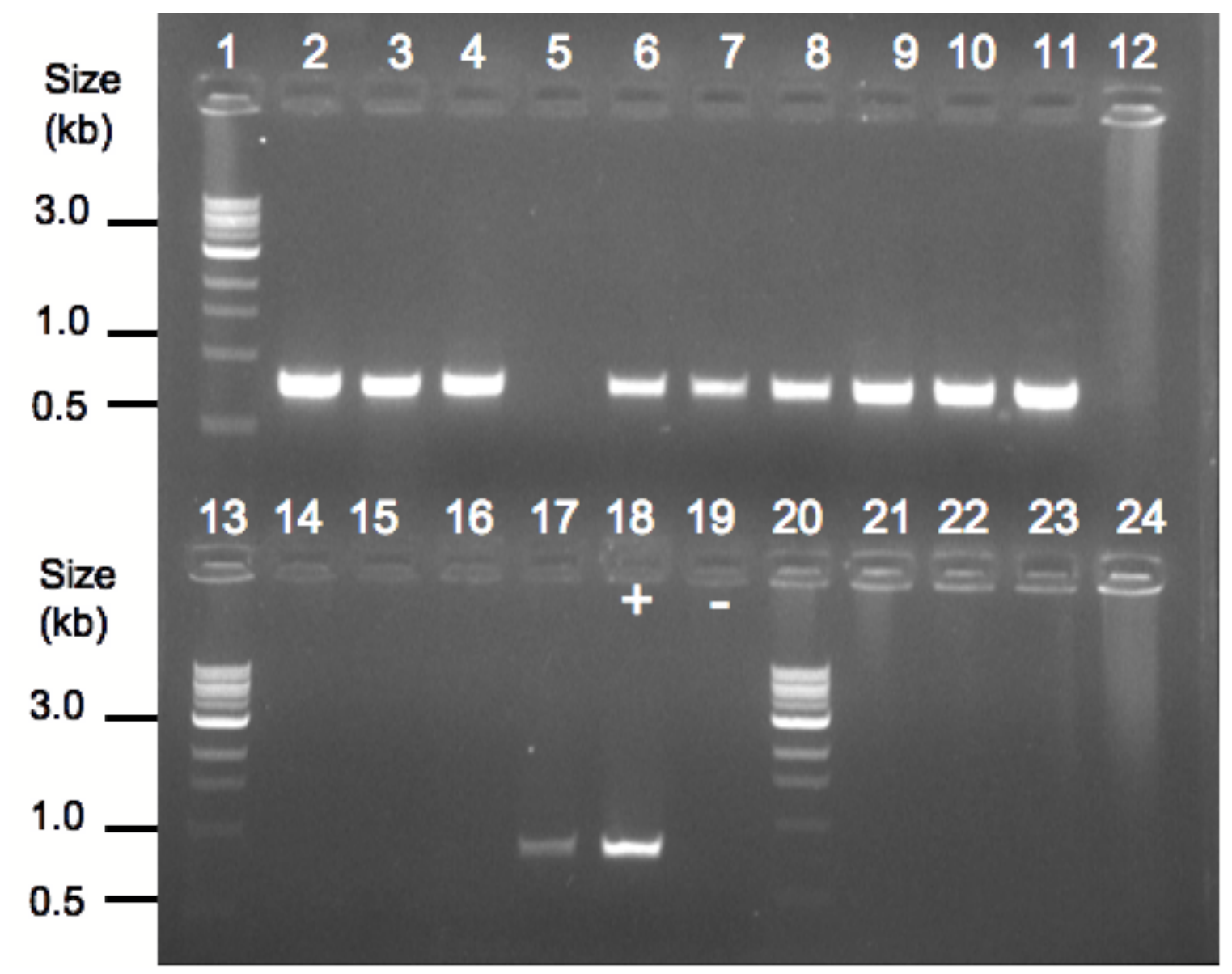

Figure 8. Gel electrophoresis (1.5\% agarose gel stained with EtBr) of internal transcribed spacer region (ITS) PCR products from the Tommeløya, Ny Ålesund, and Rossøya populations compared to a $1 \mathrm{~kb}$ DNA ladder. Expected amplicon lengths: $S$.

groenlandica $=739 \mathrm{bp}$, L. digitata $=739 \mathrm{bp}$ and L. solidungula $=740 \mathrm{bp}$. Lanes $2-11$ and 17 (2.T_22,3.T_23,4.T_24,5.T_26,6.T_27, 7.T_28,8.T_29C,9. Tommeløya \#1, 10.

Tommeløya \#4, 11.NA_03a, 17.R_10) correspond to S. groenlandica and Lanes 14-16 (14.Lsoli\#19, 15.Lsoli\#22, 16.Lsoli\#25) show L. solidungula COI sequences for Svalbard samples. Lane 18 shows the positive control (+) and Lane 19 shows the negative control (-). Lanes 12, 21-24 were empty. 


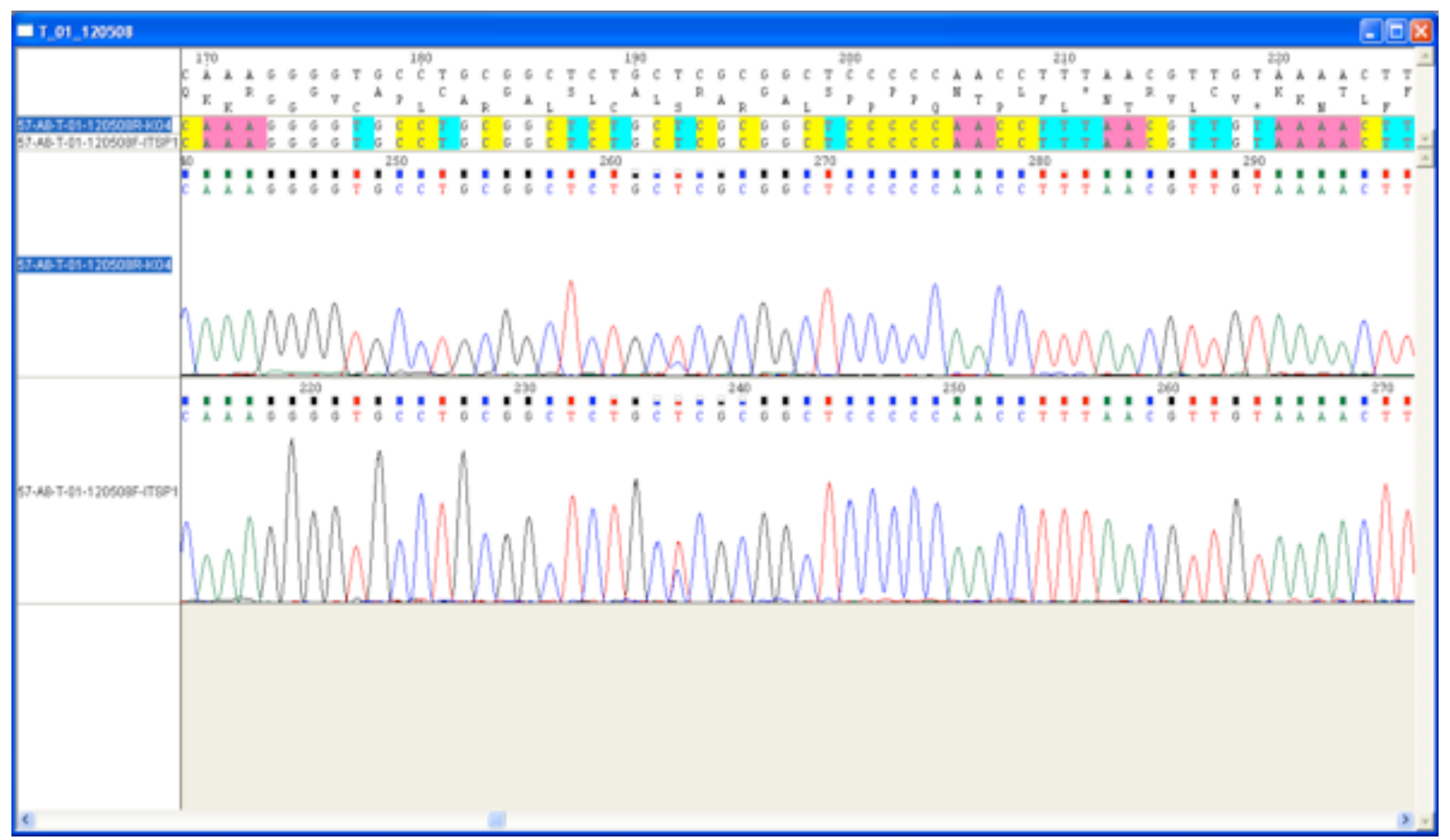

Figure 9. Chromatogram/trace alignments of forward and reverse reads of the ITS sequence using Chromas Pro software to align and check the reads for a specimen from the Tommeløya population. At nucleotide site 192 there appears to be an ambiguous base call, that may represent a polymorphic site in the ITS region. 


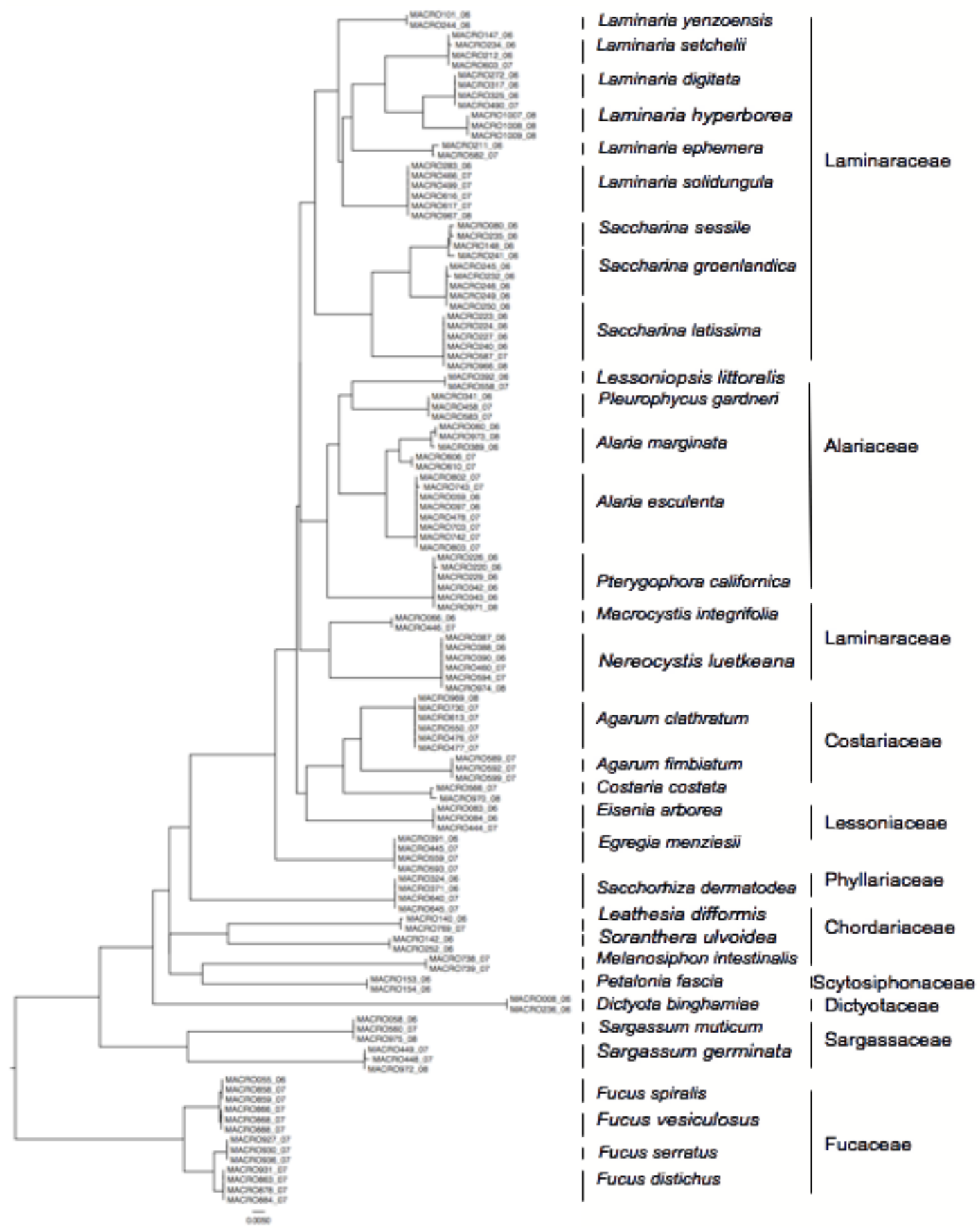

Figure 10. Neighbor-joining tree using only sequences from McDevit \& Saunders (2009) to recreate a phylogram of species relatedness to compare methods utilized in this study with those utilized by McDevit \& Saunders (2009). Tree created by enforcing the GTR model of evolution and arbitrarily rooting the tree on the Fucus sp. branch. 


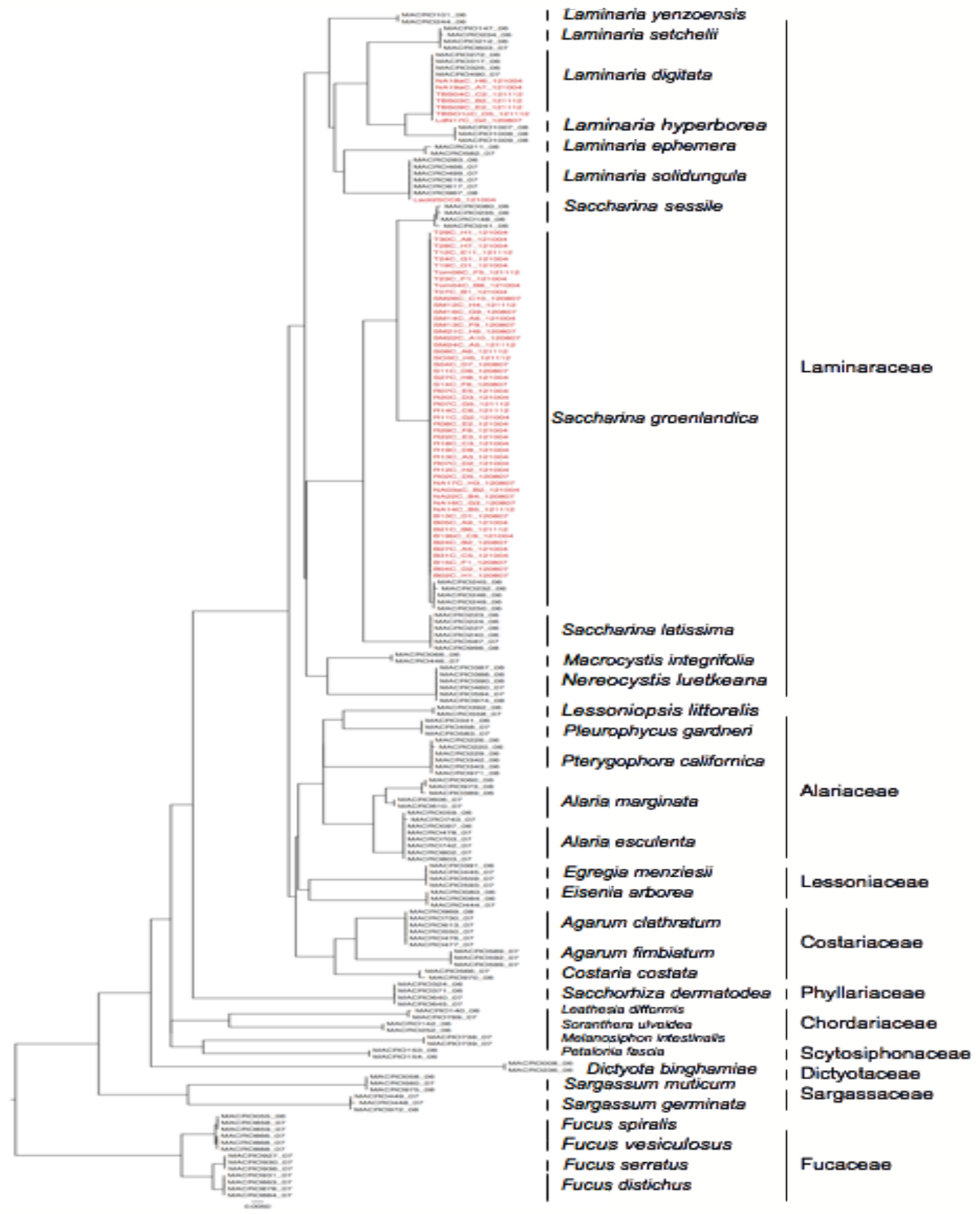

Figure 11. Neighbor-joining (NJ) phylogram of sequences derived from this study and analyzed with McDevit \& Saunders (2009) COI sequences (BOLD 2014). Distances corrected using the GTR model of evolution. McDevit \& Saunders (2009) taxon shown in black. Taxon for sequences derived in this study shown in red. 


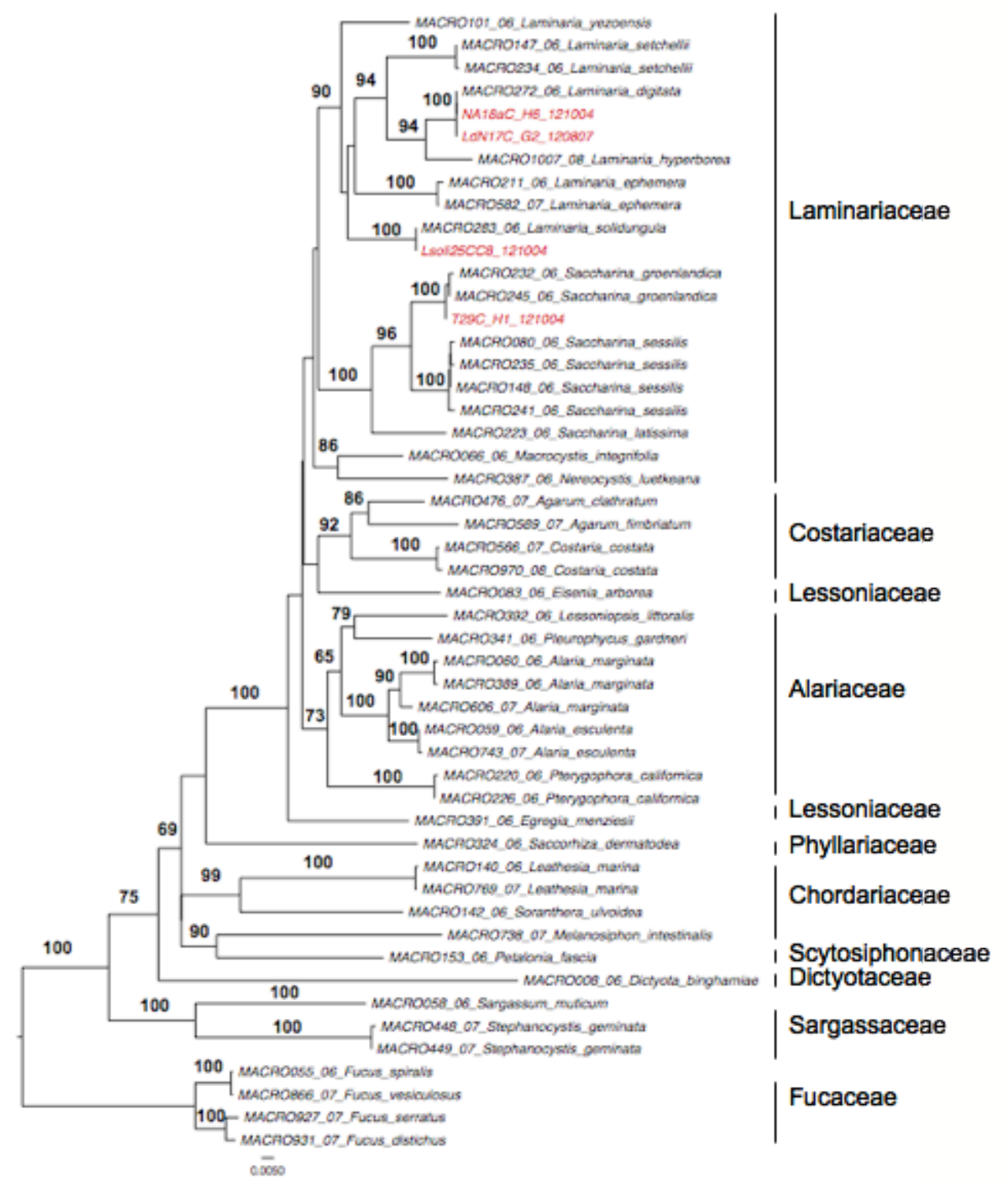

Figure 12. Neighbor-joining phylogram enforcing a GTR model of evolution for all unique COI sequences from the McDevit \& Saunders (2009) data set and sequences derived in this study. Bootstrap values (nreps=1000) are shown above each branch. The McDevit \& Saunders (2009) taxon based on BOLD identification numbers (McDevit and Saunders 2009) are shown in black text. Taxon derived from this study shown in red. 


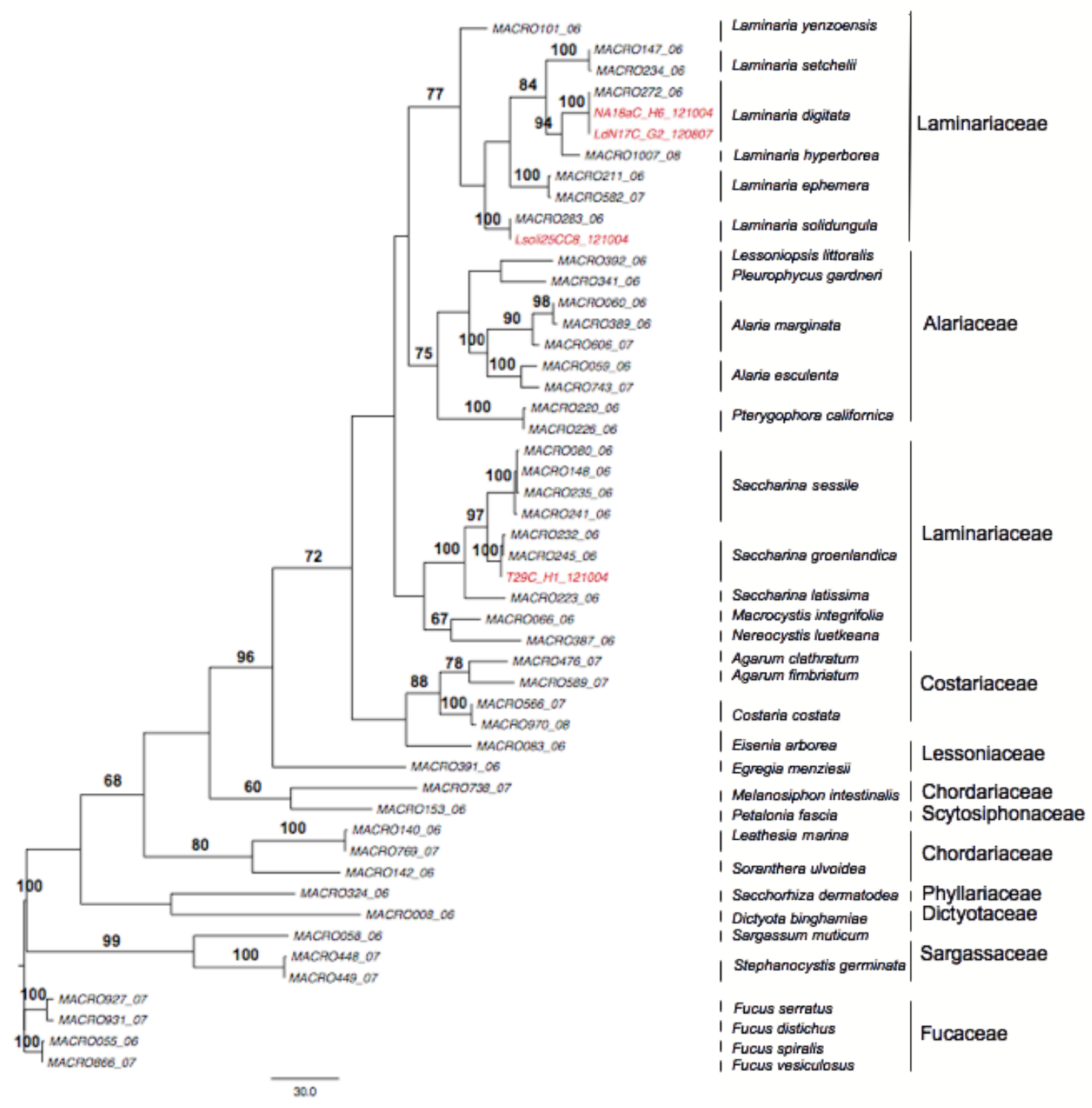

Figure 13. Parsimony tree (heuristic search nreps $=40$ ) of all unique COI sequences from McDevit \& Saunders (2009) and all sequences derived from this study. Fifty percent majority rule bootstrap values (nreps=1000) are shown above or below the appropriate branches. Taxon from McDevit \& Saunders (2009) are shown in black text. Taxon derived in this study shown in red text. Scale bar indicates a tree length of 30.0 . 


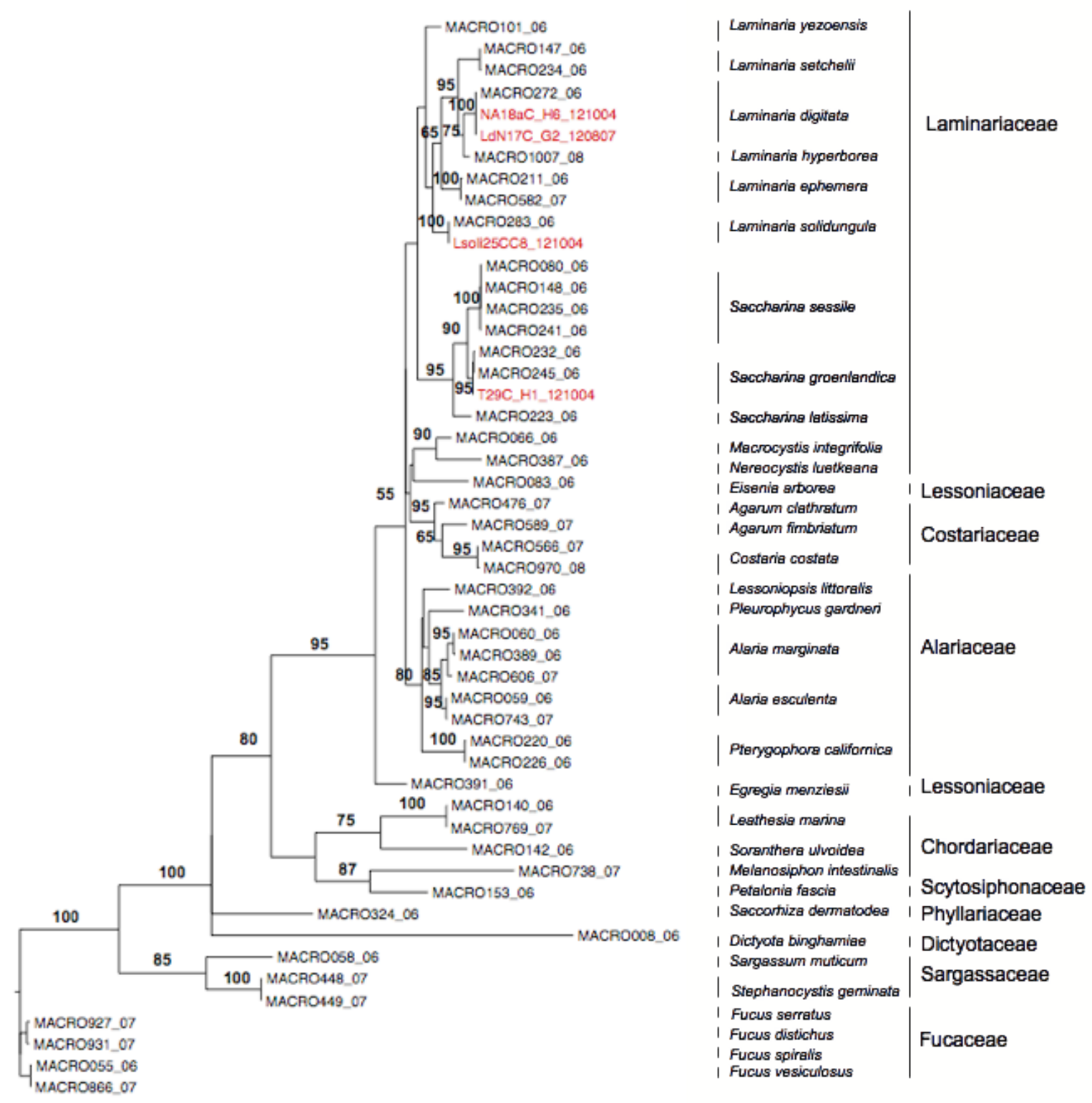

Figure 14. Maximum likelihood phylogram enforcing the TVM $+\mathrm{I}+\mathrm{G}$ model of evolution and substitution for the COI gene region using the McDevit \& Saunders (2009) and sequences derived here. McDevit \& Saunders (2009) taxon shown in black text. Sequences derived in this study shown in red text. Bootstrap values (nreps=20) are shown above or below the appropriate branch. 


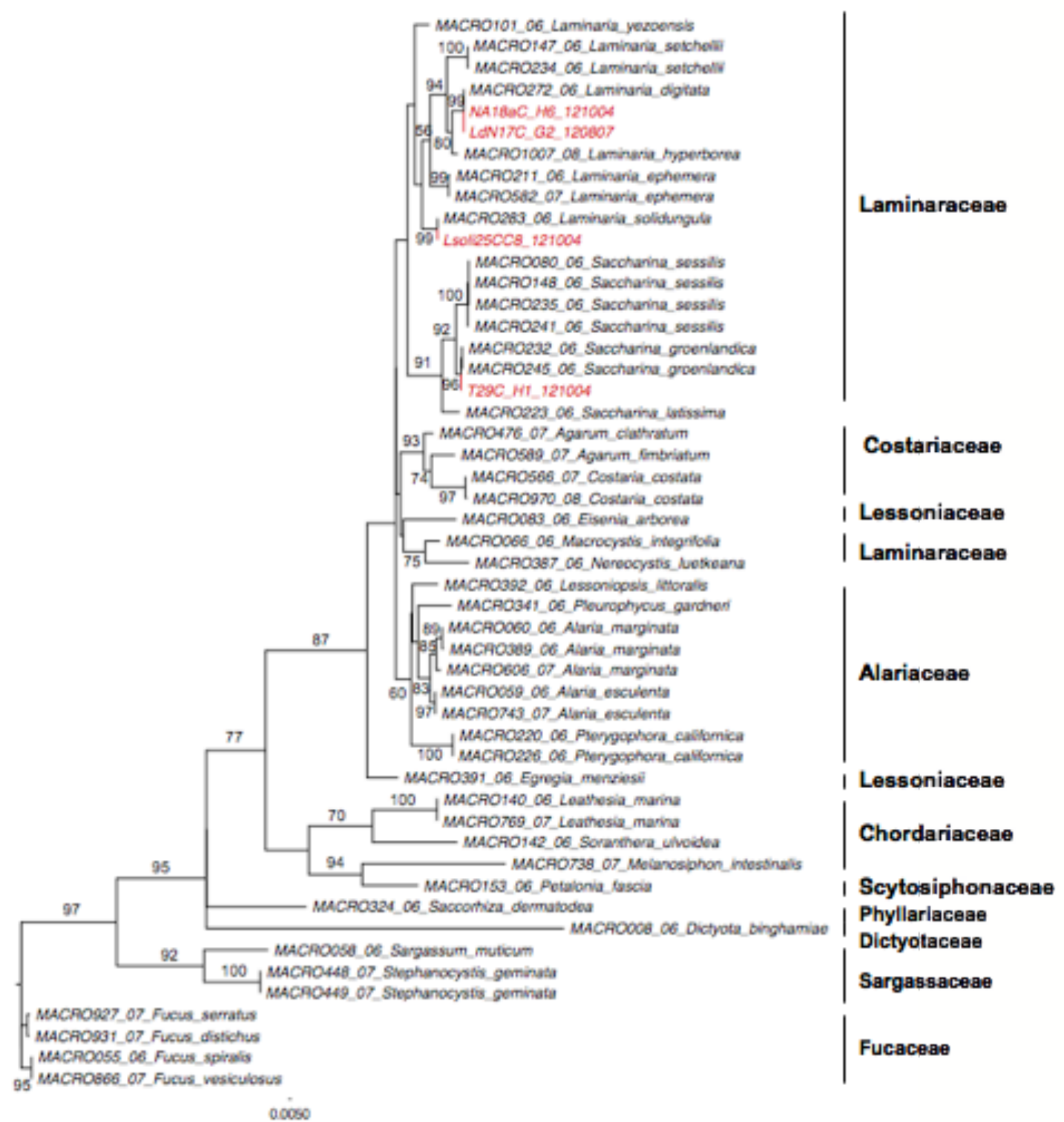

Figure 15. Maximum likelihood tree enforcing the TPM1 uf $+\mathrm{I}+\mathrm{G}$ model of evolution for the COI gene region. Fifty-percent majority rule bootstrap (nreps=1000) values are shown above or below the appropriate branch. Taxon derived from this study shown in red text. Taxon from McDevit \& Saunders (2009) shown in black text. 
MACR0272 06 Lami. vs. MACR0232 06 Sacc:

\begin{tabular}{crrrr|r} 
& A & C & G & T & totals \\
\hline--- & 124 & 0 & 5 & 2 & 131 \\
A & 3 & 193 & 1 & 11 & 118 \\
C & 13 & 0 & 124 & 4 & 141 \\
G & 4 & 11 & 6 & 247 & 268 \\
T & 144 & 114 & 136 & 264 & 658 \\
totals & 144 &
\end{tabular}

Proportion of sites differing $=60 / 658=0.0912$

Apparent transition/transversion ratio $=40 / 20=2.0000$

MACR0272 06 Lami. vs. MACR0245 06 Sacc:

\begin{tabular}{crrrr|r} 
& A & C & G & T & totals \\
\hline---- & 124 & 0 & 5 & 2 & 131 \\
A & 3 & 104 & 1 & 10 & 118 \\
C & 13 & 0 & 124 & 4 & 141 \\
G & 4 & 11 & 6 & 247 & 268 \\
T & 144 & 115 & 136 & 263 & 658 \\
totals & 144
\end{tabular}

Proportion of sites differing $=59 / 658=0.0897$

Apparent transition/transversion ratio $=39 / 20=1.9500$

MACR0272 06 Lami. vs. T29C H1 121004:

\begin{tabular}{|c|c|c|c|c|c|}
\hline & A & $\mathrm{C}$ & G & $\mathrm{T}$ & totals \\
\hline A & 124 & 0 & 5 & 21 & 131 \\
\hline C & 3 & 104 & 1 & $10 \mid$ & 118 \\
\hline G & 13 & 0 & 124 & 41 & 141 \\
\hline $\mathrm{T}$ & 4 & 10 & 6 & 2481 & 268 \\
\hline totals & 144 & 114 & 136 & 2641 & 658 \\
\hline
\end{tabular}

Proportion of sites differing $=58 / 658=0.0881$

Apparent transition/transversion ratio $=38 / 20=1.9000$

Figure 16. Actual interspecific nucleotide pairwise differences between Laminaria digitata (MACR0272_06) and Saccharina groenlandica (MACR0232_06, MACR0245_06 and T_29C_H1_121004). 
LdN17C G2 120807 vs. MACR0232 06 Sacc:

\begin{tabular}{|c|c|c|c|c|c|}
\hline & A & $\mathrm{C}$ & G & $\mathrm{T}$ & totals \\
\hline A & 124 & $\theta$ & 5 & 21 & 131 \\
\hline C & 3 & 193 & 1 & 11 I & 118 \\
\hline G & 13 & 0 & 124 & 41 & 141 \\
\hline $\mathrm{T}$ & 4 & 11 & 6 & 247 I & 268 \\
\hline totals & 144 & 114 & 136 & $264 \mid$ & 658 \\
\hline
\end{tabular}

LdN17C G2 120807 vs. MACR0245 06 Sgcc:

\begin{tabular}{crrrrr} 
& A & C & G & T & totals \\
\hline- & 124 & 0 & 5 & 2 & 131 \\
A & 3 & 194 & 1 & 10 & 118 \\
C & 13 & 0 & 124 & 4 & 141 \\
G & 4 & 11 & 6 & 247 & 268 \\
T & 144 & 115 & 136 & 263 & 658
\end{tabular}

Proportion of sites differing $=59 / 658=0.0897$

Apparent transition/transversion ratio $=39 / 20=1.9500$

LdN17C G2 129807 vs. T29C H1 121004:

\begin{tabular}{|c|c|c|c|c|c|}
\hline & A & $\mathrm{c}$ & $\mathrm{G}$ & $\mathrm{T}$ & totals \\
\hline A & 124 & 0 & 5 & 21 & 131 \\
\hline C & 3 & 104 & 1 & 101 & 118 \\
\hline G & 13 & 0 & 124 & 41 & 141 \\
\hline$T$ & 4 & 10 & 6 & 2481 & 268 \\
\hline totals & 144 & 114 & 136 & 2641 & 658 \\
\hline
\end{tabular}

Figure 17. Actual interspecific nucleotide pairwise differences between Laminaria digitata (LDN17C_G2_120807) and Saccharina groenlandica (MACR0232_06, MACR0245_06 and T_29C_H1_121004). 
MACR0272 06 Lami. vs. NA18aC H6 121004:

\begin{tabular}{|c|c|c|c|c|c|}
\hline & A & $\mathrm{C}$ & G & $T$ & totals \\
\hline A & 131 & 0 & 0 & 01 & 131 \\
\hline $\mathrm{C}$ & 0 & 118 & 0 & 01 & 118 \\
\hline 6 & 0 & 0 & 141 & 01 & 141 \\
\hline $\mathrm{T}$ & 0 & 0 & 0 & 2681 & 268 \\
\hline
\end{tabular}

Proportion of sites differing $=0 / 658=0.0000$

Apparent transition/transversion ratio $=0 / 0=$ undef ined

MACR0272 06 Lami. vs. LdN17C G2 120807:

\begin{tabular}{rrrrr|r} 
& A & C & G & T & totals \\
\hline--131 & 0 & 0 & 0 & 131 \\
A & 13 & 118 & 0 & 0 & 118 \\
C & 0 & 0 & 141 & 0 & 141 \\
G & 0 & 0 & 0 & 268 & 268 \\
T & 0 & 0 & 0 & \\
-131 & 118 & 141 & 268 & 658
\end{tabular}

Proportion of sites differing $=0 / 658=0.0000$

Apparent transition/transversion ratio $=0 / 0=$ undef ined

Figure 18. Actual intraspecific nucleotide pairwise differences for L. digitata sequences from McDevit \& Saunders (2009) (MACRO272_06_Laminaria digitata), the NA_18 specimen from Ny Ålesund and the North Wales sample LdNWAL17 (tissue sample courtesy of the Claire Lab, Roscoff, France). 
NA18aC H6 121004 vs. MACR0232 06 Sacc:

\begin{tabular}{|c|c|c|c|c|c|}
\hline & A & C & G & $\mathrm{T}$ & totals \\
\hline A & 124 & 0 & 5 & 21 & 131 \\
\hline C & 3 & 103 & 1 & $11 \mid$ & 118 \\
\hline G & 13 & 0 & 124 & 4 & 141 \\
\hline $\mathrm{T}$ & 4 & 11 & 6 & 247 I & 268 \\
\hline totals & 144 & 114 & 136 & $264 \mid$ & 658 \\
\hline
\end{tabular}

Proportion of sites differing $=60 / 658=0.0912$

Apparent transition/transversion ratio $=40 / 20=2.0000$

NA18aC H6 121004 vs. MACR0245 66 Sac:

\begin{tabular}{crrrr|r} 
& A & C & G & T & totals \\
\hline A & 124 & 0 & 5 & 2 & 131 \\
C & 3 & 164 & 1 & 10 & 118 \\
G & 13 & 0 & 124 & 4 & 141 \\
T & 4 & 11 & 6 & 247 & 268 \\
totals & 144 & 115 & 136 & 263 & 658
\end{tabular}

Proportion of sites differing $=59 / 658=0.0897$

Apparent transition/transversion ratio $=39 / 20=1.9500$

NA18aC H6 121004 vs. T29C H1 121004:

\begin{tabular}{crrrrr} 
& A & C & G & T & totals \\
\hline- & & C & & & \\
A & 124 & $G$ & 5 & 2 & 131 \\
C & 3 & 104 & 1 & 10 & 118 \\
G & 13 & 0 & 124 & 4 & 141 \\
T & 4 & 10 & 6 & 248 & 268 \\
\hline totals & 144 & 114 & 136 & 264 & 658
\end{tabular}

Proportion of sites differing $=58 / 658=0.0881$

Apparent transition/transversion ratio $=38 / 20=1.9000$

Figure 19. Actual interspecific nucleotide pairwise differences between Laminaria

digitata (NA18aC_H6_121004) and Saccharina groenlandica (MACR0232_06, MACR0245_06 and T_29C_H1_121004). 
MACR0232 06 Sacc. vs. MACR0245 06 Sacc:

\begin{tabular}{|c|c|c|c|c|c|}
\hline & A & C & G & $\mathrm{T}$ & totals \\
\hline A & 144 & 0 & 0 & 01 & 144 \\
\hline C & 0 & 114 & 0 & 01 & 114 \\
\hline G & 0 & 0 & 136 & 01 & 136 \\
\hline$T$ & 0 & 1 & 0 & 2631 & 264 \\
\hline totals & 144 & 115 & 136 & 2631 & 658 \\
\hline
\end{tabular}

Proportion of sites differing $=1 / 658=0.0015$

Apparent transition/transversion ratio $=1 / 0=$ undef ined

MACR0232 06 SgCC. vs. T29C H1 121004:

\begin{tabular}{crrrrrr} 
& A & C & G & T & totals \\
\hline- & 144 & 0 & 0 & 0 & 144 \\
A & 0 & 113 & 0 & 1 & 114 \\
C & 0 & 0 & 136 & 0 & 136 \\
G & 0 & 1 & 0 & 263 & 264 \\
T & 0 & 1 & -136 & 264 & 658
\end{tabular}

Proportion of sites differing $=2 / 658=0.0630$

Apparent transition/transversion ratio $=2 / 0=$ undef ined

MACR0245 06 Sacc. vs. T29C H1 121004:

\begin{tabular}{|c|c|c|c|c|c|}
\hline & A & $\mathrm{C}$ & G & $T$ & totals \\
\hline A & 144 & $\theta$ & 0 & 01 & 144 \\
\hline C & 0 & 114 & 0 & 11 & 115 \\
\hline G & 0 & 0 & 136 & 01 & 136 \\
\hline $\mathrm{T}$ & 0 & 0 & 0 & 2631 & 263 \\
\hline totals & 144 & 114 & 136 & $264 \mid$ & 658 \\
\hline
\end{tabular}

Proportion of sites differing $=1 / 658=0.0015$

Apparent transition/transversion ratio $=1 / 0=$ undef ined

Figure 20. Actual intraspecific nucleotide pairwise differences between Saccharina groenlandica sequences (MACR0232_06, MACR0245_06 and T_29C_H1_121004). 


\begin{tabular}{|c|c|c|c|c|c|c|c|c|c|c|c|c|c|c|c|c|c|c|c|c|c|c|c|c|c|c|c|c|c|c|c|c|c|c|c|c|c|}
\hline & Charact & 91 & 92 & 93 & 94 & 95 & 96 & 97 & 98 & 99 & 100 & 101 & 102 & 103 & 104 & 105 & 106 & 107 & 108 & 109 & 110 & 111 & 112 & 113 & 114 & 115 & 116 & 117 & 118 & 119 & 120 & 121 & 122 & 123 & 124 & 125 & 5126 \\
\hline Taxa & & & & & & & & & & & & & & & & & 1. & & & & & & & & & & & 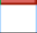 & & & & & & & & & \\
\hline 1 & MACR027206 Laminaria digitata & $A$ & $T$ & $T$ & $T$ & $T$ & $T$ & A & G & 6 & $G$ & G & 6 & 6 & A & A & $T$ & c & $A$ & $T$ & c & $A$ & $G$ & $T$ & $T$ & G & $T$ & $A$ & & & & $c$ & G & $T$ & $T$ & A & $T$ \\
\hline 2 & NA18aC H6 121004 & A & $T$ & $T$ & $T$ & $\mathrm{~T}$ & $T$ & A & G & 6 & 6 & G & 6 & G & A & A & $T$ & c & A & $T$ & c & A & G & $T$ & $T$ & 6 & $T$ & A & & & & c & G & T & T & A & T \\
\hline 4 & MACR0283 06 Laminaria solidungula & A & $T$ & $T$ & $T$ & $T$ & $T$ & A & G & G & A & G & G & 6 & A & A & $T$ & c & A & $T$ & c & A & G & $T$ & $T$ & G & $T$ & A & & & & $T$ & G & $T$ & T & A & T \\
\hline 5 & Lsoli25CC8 121004 & A & $T$ & $T$ & $T$ & $\mathrm{~T}$ & $T$ & A & G & 6 & A & 6 & 6 & 6 & A & A & T & c & A & $T$ & c & A & G & $T$ & $T$ & 6 & $T$ & A & & & & $T$ & G & $T$ & $T$ & A & T \\
\hline 6 & MACR023206 Saccharina groenlandica & A & $T$ & $T$ & $T$ & $\mathrm{~T}$ & T & A & G & 6 & A & 6 & G & & & & c & c & A & c & c & A & 6 & $T$ & $T$ & A & $T$ & A & $c$ & A & A & $T$ & 6 & $T$ & T & A & T \\
\hline 7 & MACR0245 06 Saccharina groenlandica & A & $T$ & $T$ & $T$ & $T$ & $T$ & A & G & 6 & A & $G$ & G & & & & c & C & A & C & C & A & 6 & $T$ & $T$ & A & $T$ & A & c & $A$ & A & $T$ & G & $T$ & T & A & T \\
\hline 8 & T29C H1 121004 & A & $T$ & $T$ & $T$ & $\mathrm{~T}$ & $T$ & A & G & 6 & A & G & G & & & & $T$ & c & A & c & C & $A$ & G & $T$ & $T$ & A & $T$ & A & C & $A$ & A & $T$ & G & $\mathrm{T}$ & $T$ & A & T \\
\hline
\end{tabular}

Figure 21. COI DNA sequences for select Laminariaceae specimens showing the coded amino acids. A nucleotide change at position 106 in the MACRO232_06 and MACRO245_06 results in an amino acid change in these $S$. groenlandica amino acid sequence from a serine $(\mathrm{S})$ to a proline $(\mathrm{P})$. 